\title{
COVID-19, State Capacity, ANd Political Violence by Nonstate ACtors
}

\author{
Brittney Koehnlein \\ Department of Political Science | Indiana University (Email: bdkoehnl@iu.edu)
}

\author{
Ore Koren \\ Department of Political Science | Indiana University (Email: okoren@iu.edu)
}

\begin{abstract}
The COVID-19 pandemic has constrained the ability of states across the world to govern and control their territories. As the state reduces its activities, space opens up for violent nonstate actors working for and against the state to fill the vacuum. Highlighting this trend, the present study evaluates the effects of COVID-19 and pandemics more broadly on attacks by nonstate actors. Our theory emphasizes the incentives of both rebels and pro-government nonstate actors (PGNs) to increase their attack frequency as disease spreads and the state retracts its governance activities to preserve resources needed elsewhere. In the first case, we highlight how the pandemic allows rebels to reduce asymmetries of power with respect to the military and establish themselves as a viable government alternative. In the second case, PGNs, which provide an alternative to militaries, are deployed to these contested spaces to thwart or preempt rebellion during the pandemic. Employing daily level data on the annual change in armed conflict and COVID-19 cases across 127 countries between 1 January 2020 and 15 June 2020, we test both claims using an econometric identification strategy. We do not find clear evidence that COVID-19 led to a higher frequency of rebel attacks, suggesting that these groups prefer to bolster their standing using nonviolent means, or avoid fighting and preserve their resources. In contrast, we find that the frequency of PGN attacks has increased with COVID-19 prevalence compared with last year. Case studies of insurgent and PGN activity in Afghanistan and Nigeria lend additional support to these results, illustrating some underlying mechanisms. Our findings explore overlooked challenges that pandemics and other disasters pose to conflict mitigation and the role PGNs play in these contexts.
\end{abstract}

Keywords: covid-19; civil war; pandemics; pro-government militia; rebels; political violence 
This study examines how COVID-19 has affected levels of violence by armed nonstate actors, including progovernment nonstate (PGN) groups, such as militias, paramilitaries, and mercenaries, and antigovernment groups (rebels, insurgents). By "nonstate actors," we refer to a spectrum of armed organizations and groups, ranging from fully organized and militarized rebel groups to loosely structured civilian defense councils. These groups can work for - or at least not against the state, or directly against it. This definition includes all pro-government militias, informal paramilitaries, auxiliaries, mercenaries (see, e.g., Carey et al., 2015; Raleigh \& Kishi, 2020), as well as antigovernment groups of rebels and insurgents. Nonstate actor activity ranges from benign organizational efforts (e.g., deciding in matters of local governance), through service provision (e.g., healthcare), to violent pro- or antigovernment action and civilian victimization (e.g., Koren, 2017; Ahram, 2011; Mitchell et al., 2014).

Theoretically, there are multiple possible linkages between COVID-19 and violence by nonstate groups, but we focus on one we believe is key - namely, the disruption to state capacity and control caused by the pandemic. We argue that, as governments scale back their governance activities due to the pandemic, especially in contested regions, space opens up for nonstate actors working both for and against the state to establish themselves as key players. For rebels and insurgents, COVID-19 'balances the playing field,' allowing them to take advantage of the government's sudden weakness and challenge the state both on the battlefield (e.g., Bagozzi, 2016) and as service and governance provider (Cunningham \& Loyle, 2020). Faced with shocks to their activities posed by COVID-19, governments may turn to pro-government nonstate actors (PGNs) such as militias, auxiliaries, paramilitaries, and mercenaries to help in thwarting or preempting rebellion intensification (Ahram, 2011; Carey et al., 2015; Raleigh \& Kishi, 2020).

Based on daily data at the country level, the empirical results indicate that between 1 
January and 15 June 2020, the spread of COVID-19 did not lead to a noticeable increase in the number of rebel attacks compared with the previous year (2019). However, we do find that - over the same period - the spread of COVID-19 caused a noticeable increase in the number of PGN attacks compared with the previous year, on average. To provide a more nuanced evaluation of these results and identify the exact pathway linking COVID-19 with violence by rebels and PGNs, we additionally report two case studies of the civil wars in Afghanistan and Nigeria. Importantly, even though we do not find clear evidence that COVID-19 increased the frequency of rebel attacks compared with last year, the results are also incompatible with the claim that COVID-19 led to an overall pacification in either rebel or PGNs activity, although (as we show in the case study section) this might have happened in some contexts.

Considering the grave possibility that COVID-19 will continue to spread and become endemic, especially in developing and conflict-afflicted states (Gates, 2020), our findings suggest that nonstate actor conflict patterns may correspondingly intensify. However, even if COVID-19 is defeated and government activities, including in areas of security and defense, return to normal, our findings still highlight the negative implications of pandemics and disease to conflict and stability. Indeed, many conflict-afflicted states already face ongoing pandemics that are even more severe and deadly than COVID-19, including tuberculosis, HIV, malaria, and Ebola. In line with past studies (e.g., Bagozzi, 2016; Cervellati et al., 2017; Kustra, 2017; Ostergard, 2004), our findings confirm that pandemics affect armed conflict, and we add to this literature by including pro-government groups in our analysis. As such, these results are relevant to both conflict scholars and policymakers working to prevent violence.

Our results do not imply that pandemics, and COVID-19 in particular, are the only or predominant cause of violence by nonstate actors, as ample research has established (e.g., Fearon 
\& Laitin, 2003; Herbst 2000; Carey et al. 2015). Rather, the objective of this article is to evaluate for the first time (to our knowledge) whether COVID-19, as an example of a fast-spreading global pandemic, has contributed to civil war, while theorizing about the precise underlying mechanism(s). Considering that our results hold across numerous sensitivity analyses, including a set of models designed specifically to account for possible endogeneity between COVID-19 and conflict (see Supplemental Appendix), our findings suggest scholars and policymakers should consider the role of pandemics when studying the determinants of violence by nonstate actors.

\section{COVID-19, State Capacity, and Violent Nonstate Actors}

In this section we develop our theoretical argument, explicating the link between COVID-19 and weakening state capacity, then discussing in detail the expected response of each nonstate actor type. In developing our theory, we build on the large body of research on the impact of natural disasters on political and socioeconomic phenomena.

\section{Theoretical motivation}

Recently, researchers began to pay more attention to the role of disasters and unplanned critical events (e.g., Reinhardt \& Ross, 2015; Jonkman \& Kelman, 2005) - especially those engendered by environmental shocks such as droughts, floods, and heatwaves (e.g., Bagozzi et al., 2017; von Uexkull et al., 2016; Ide, 2016) - in generating conflict and violence. Scholars have identified several potential pathways linking environmental shocks with conflict, including through exacerbating grievances (e.g., von Uexkull et al., 2016; Ide, 2016), intensifying competition over agricultural resources (Bagozzi et al., 2017), and increasing strain on food and traditional herding systems (e.g., Bellemare, 2015; Döring, 2020). 
The ways in which natural disasters affect conflict vary, but past research suggests that natural disasters exacerbate weak state capacity and that weak states are further weakened by natural disasters through a variety of mechanisms, including unsuccessful relief operations (Berariu et al., 2015; Chattu \& Knight, 2019), destruction of the natural environment (Dauvergne, 1998; Eastin, 2016), and political mismanagement of the disaster (Lin, 2015; McLean \& Whang, 2021; Nel \& Righarts, 2008). In the latter case, McLean \& Whang (2021), for instance, find that weak states tend to divert funds away from natural disaster preparedness and mitigation, which ultimately compounds the effects of natural disasters when they strike. This diversion of funds is further compounded when states are facing economic sanctions or are undergoing an economic crisis, as these states have fewer resources than average and often sacrifice funds toward nonimminent threats. Given that weak states have limited resources before a natural disaster strikes, using limited resources for disaster mitigation and relief strains the regime.

Moreover, if the regime is also engaged in an ongoing conflict, it will further limit the resources available to fight that conflict as well as limit the resources for disaster relief (Eastin, 2016; Nel \& Righarts, 2008). Eastin (2016) specifically finds that a natural disaster increases a conflict's duration because it decreases a state's capacity to suppress an insurgency. A regime's capacity therefore shrinks when its resources are split between fighting a conflict and mitigating a natural disaster. This limits a regime's ability to fight (potentially prolonging the conflict) and provide disaster relief (potentially prolonging and exacerbating the disaster's effects). Under these circumstances, the government's attention is diverted, which creates opportunities for non-state actors to either launch attacks or administer aid. This is particularly relevant for our discussion, as we explain in the next subsection. 
One type of disaster that has received surprisingly little attention until recently is disease. Like other unplanned disasters, disease outbreak, and in particular pandemics - outbreaks that affect wide geographic areas and impact the lives of hundreds of thousands if not millions of individuals (Bagozzi \& Koren, 2021) - is often difficult to predict and challenging to mitigate. Widespread disease, especially if it becomes endemic (constantly present), can have major negative socioeconomic impacts on states, especially those states with limited state capacity and resources (Gallup \& Sachs, 2000; Bagozzi \& Koren, 2021).

For example, a study by Gallup and Sachs (2000) showed that during the latter part of the $20^{\text {th }}$ century, malarial countries grew $1.3 \%$ less per person per year compared with non-malarial states, even after accounting for initial poverty, economic policy, tropical location, and life expectancy. Similarly, Bagozzi and Koren (2021: 9-10) find that increases from minimum to maximum in a given state's malarial prevalence decreases the probability that affected states will receive a diplomatic mission from another state by $6-7 \%$. Diseases such as HIV/AIDS, malaria, tuberculosis, influenza, cholera, and SARS have all reached pandemic levels in the last century with devastating effects (Bagozzi \& Koren, 2021). Developing, and especially conflict-torn countries with already weak infrastructures, poor safety nets, and shaky health systems, bear a much greater cost of pandemics and often suffer from graver long-term consequences of diseases and pandemics (Ataguba, 2020).

\section{COVID-19 and weakening state capacity}

From this perspective, like other natural disasters, the sudden spread of disease constitutes a governance shock, in particular to states' administrative and bureaucratic capacities. Accordingly, we focus on the formal governance aspect of state capacity, which encompasses a wide range of 
concepts. For our purposes, formal governance refers to the ability of the state to penetrate society and control and administer its territory (Skopcol, 1985; Herbst, 2000; Hendrix, 2010). This notion builds on the definition of bureaucratic/administrative capacity developed by, e.g., Fearon \& Laitin (2003), Hendrix (2010), and Koren \& Sarbahi (2018), which "shifts the focus from the state's ability to put boots and arms in the field to its ability to collect and manage information" (Hendrix, 2010, 274). Weak states often struggle to obtain information, control, and regulate political and socioeconomic activity within their boundaries, providing an opportunity for rebel groups and nonstate actors to use this to their advantage (Herbst, 2000; Fearon \& Laitin, 2003). Strong states, in contrast, are far more effective at administrating their territory, which allows them to collect information, maintain local control, and effectively identify potential attacks by anti-state actors. Such states therefore have higher formal governance and state capacity levels (Koren \& Sarbahi, 2018).

In particular, due to their high unpredictability and speed of spread, pandemics can disrupt governance and control in multiple ways. Addressing and combating pandemic diseases strains government resources, limiting governments' ability to tackle issues that are not directly related to the pandemic (Ataguba, 2020; Bagozzi, 2016; Davies, 2013; Elbe, 2002; Elbe, 2005; Enemark, 2017; Kim, 2018; Ruckstuhl et al., 2017). The government must shift its focus from other administrative functions to combating the disease, while simultaneously being forced to reduce its bureaucratic and even security operations to avoid infection and the spread of the pandemic to its employees and troops. As disease spreads, government institutions close down or switch to operating in emergency mode, and even military activities are reduced to the bare minimum (e.g., U.S. Army, 2020). This further constrains the ability of the state to conduct testing and establish emergency facilities in many (remote and rural) areas, thus creating a 'governance vacuum' in 
these regions. Pandemics, especially ones that emerge suddenly and spread fast, like COVID-19, therefore lead to an overall sudden and sharp decrease in state capacity and presence, therein reducing the state's ability to govern and administer remote areas, which is especially true for states that had limited resources and low state capacity to begin with (Bagozzi, 2016).

In the case of COVID-19, as governments cannot guarantee that they can exercise control over some regions, especially remote or rural ones, nonstate actors - operating for or against the state - move in (Herbst, 2000; Fearon \& Laitin 2003; Cunningham \& Loyle, 2020). Accordingly, the relationship between the state and nonstate actors is defined by an asymmetry of power; in strong states, these asymmetries of power greatly favor the formal state and its institutions, while in weak and weakened states these asymmetries are more balanced and may favor nonstate actors in some (often remote) regions (Fearon \& Laitin, 2003).

It is important to emphasize that while we focus on the violent outcomes of COVID-19induced declines in administrative state capacity, it is possible that, at least in the short term, these nonstate actors will seek to illustrate that they are a viable alternative to the state, taking on local governance and even helping with tackling the pandemic (which happened in the case of the Taliban, as we discuss below). They may also lay low to avoid the virus, especially if supply lines have been affected, requiring them to spend time adjusting rather than fighting. Third, both proand anti-government forces may withdraw to avoid adding to the instability (as happened, for instance, in Yemen as COVID-19 began spreading). Finally, outside sponsors may not be able to provide the same level of support as they deal with COVID-19's impacts domestically, forcing them to adjust their strategic priorities as illustrated e.g., by reduction in Iran's supports of Houthi rebels in Yemen or Syria (Asseburg et al., 2020). In these situations, COVID-19 will result in a pacifying, or negligible, effect on violence, at least in the short term. 
Nevertheless, we believe that focusing on violent outcomes, as we do below, is important for at least two reasons. First, nonstate actors can deploy a mix of violent and nonviolent responses to COVID-19, which can include, for example, both providing relief to civilians and increasing attacks against government outposts (the Taliban's strategy, as we discuss below) or rebel groups (as did militias in Iraq). In this case, even if COVID-19 has induced pacifying effects in some conflict contexts it could, at the same time, led to increases in rates of violence. Second, we believe that, considering the social and political costs of violence by nonstate actors, it is crucial to understand the factors that lead to its intensification. In light of the socioeconomic and political costs of violence, the fact that COVID-19 might lead to pacification in some contexts is far less important than the possibility that it may lead to violence, deaths, and destruction.

\section{$\underline{\text { Implications for rebel groups }}$}

As the state retreats from - or at least reduces its administrative activity in - contested spaces to mitigate the impact of the pandemic on its institutions, troops, and employees, both anti- and progovernment nonstate forces see an opportunity. Especially for anti-government troops, this sudden disruption to state governance and control creates opportunities to address and use to their benefit existing grievances against the government (Wise \& Barry, 2017). As we discussed above, this impact could result in some pacifying effects - e.g., as all sides agree on a ceasefire to combat the pandemic (The Economist, 2020), rebels seek to avoid the disease and bolster supply chains, sponsorship activity by external states is reduced. Yet, global pandemics such as COVID-19 may also lead to conflict intensification, as rebels push against weakened governments.

With respect to the possibility of conflict intensification, scholars highlight state-weaknessrelated pathways by which pandemics operate, such as reducing asymmetries in military capability 
between the government and rebel groups (Bagozzi, 2016), intensifying the effects of ongoing environmental stress (Cervellati et al., 2017), reducing life expectancy and - by extension - the opportunity cost of conflict (Kustra, 2017), and weakening local political and military institutions (Ostergard, 2004). Accordingly, by empowering rebel groups and allowing them to take advantage of the regime's weaknesses in governance, research suggests the many effects of pandemics in war-torn countries - and in our case, COVID-19 in particular - are unlikely to lead to pacification. Indeed, as the state reduces its administrative and security activities, which forces it to take a more passive and defensive stance, the opportunity arises for rebels to go on the offensive, taking advantage of the state's suddenly reduced capacity and presence.

Therefore, in the line with the pathways discussed in the previous subsection, as COVID-19related cases and deaths increase, rebels might take advantage of the situation to reduce power asymmetries with respect to the government, increasing their administrative and military presence within regions where they were prevented from doing so before. They may also benefit from local grievances and individuals' willingness to join due to the pandemic and government retraction, as Kustra $(2017,2131)$ notes, 'as civilian life expectancy declines, this opportunity cost does too, increasing the probability of rebellion,' by facilitating rebel recruitment. In these contexts, the marginal returns from continuing and intensifying fighting under COVID-19 conditions are higher and might provide these groups with a stronger bargaining position (see, e.g., Nemeth \& Lai, this issue), even if they choose to still pursue nonviolent strategies (such as providing relief) simultaneously. While the government is distracted by disease amelioration and protecting its own employees and troops from exposure, the rebels can extract more resources and revenues with less violence than is typically necessary, as illustrated in a story by The Telegraph about the conflict in Nigeria: 
There is no doubt that Boko Haram recognises the opportunity that COVID-19 offers them. Boko Haram's breakaway group, Islamic State West Africa Province, recently boasted that the pandemic is an opportunity to step up efforts and expand activities. In an editorial in Isil central's bi-weekly Arabic language magazine, it celebrated recent attacks in the Lake Chad region. It said the virus and subsequent economic downturn would divert government attention, weaken capacity and increase fragility, giving its fighters more inroads (Bukarti, 2020a, emphasis added).

Accordingly, building on these points as well as the research and anecdotes discussed above, our first hypothesis is as follows:

H1: As COVID-19 spreads, the number of attacks by rebels will be higher compared with pre-pandemic levels.

\section{$\underline{\text { Implications for pro-government militias }}$}

While the impact of pandemics on rebel and insurgent activity received some scholarly attention, there have been no similar attempts (to our knowledge) to explore how the prevalence of disease impacts violence by pro-government nonstate groups, namely militias, auxiliaries, informal paramilitaries, and mercenaries (Raleigh \& Kishi, 2020). Yet, there are several reasons to think that pandemic spread can increase the probability that even in relatively capable countries, violence by pro-government nonstate groups' (PGNs) will rise as the pandemic progresses.

First, as we discuss above, pandemics place severe constraints on government resources and activity compared with normal times. By forcing the government to reduce operations in order to conserve resources, protect its employees and troops, and combat the disease, the pandemic creates a vacuum of governance and control. Just as rebels can move in to occupy these spaces, so can PGNs. When states are forced to reduce security operations to limit their forces' exposure, 
especially if they do not enjoy some level of immunity (Bagozzi, 2016), they may actively seek the help of local PGNs, including militias, paramilitaries, and even mercenaries.

Indeed, research identified several advantages that weak or suddenly-weakened governments gain by relying on PGNs, including low costs of training and operations (such groups get little-to-no training and often support themselves, see, e.g., Ahram 2011; Carey et al., 2015; Koren, 2017), and plausible deniability, i.e., the ability to lay blame on PGNs if violence gets out of control (Carey et al., 2015; Mitchell et al., 2014). From this perspective, PGNs, like rebel groups, proliferate where and when the state is weak, and provide a pro-regime alternative in the absence of official military capacity (Aliyev, 2016). Therefore, when faced with a sudden disruption to its administrative and security operations, the government can, in a way, "have its cake and eat it too:' to reduce operations and minimize the pandemic's impact on its forces, diverting resources to combating the disease's impacts, while still being able to exercise some degree of state control, at least by name.

Second, the costs from pandemics are often multiplied for larger and denser groups (Ataguba, 2020; Bagozzi, 2016; Sawyer, 1993). Organized militaries are often large and operate in more organized and denser contingents (e.g., companies, battalions), with soldiers living and working together, allowing disease to easily spread throughout their ranks (Bagozzi, 2016; Ostergard, 2004). In contrast, PGNs are often composed of smaller units and looser troop arrangement, considering they are more likely to fight skirmishes or attack civilians rather than get involved in direct military confrontations (Carey et al., 2015; Koren, 2017; Ahram, 2011). Pandemics', and by extension, COVID-19's costs are therefore higher for (typically larger and less diffuse) government troop deployments, which are likely to be bigger and better organized (and hence more susceptible to COVID-19's effects) compared with the more loosely organized PGNs. 
Finally, and related, any costs for PGNs incurred due to COVID-19 are often not borne directly by the regime, making them a 'cheaper alternative' - in straightforward material terms to formal state forces. Governments rarely invest the same level in recruiting, training, and equipping PGNs as they do in their official militaries (Ahram, 2011; Carey et al., 2015). Moreover, if PGNs encounter the disease, they bear the cost themselves; any repercussions will be, to a great degree, spared from state employees and troops. As formal militaries become increasingly concerned of the pandemic's effect on their combat preparedness and capability, they or their governments are more likely to switch to using PGNs in order to retain some control or at least to prevent potential anti-state groups from making gains, increasing - by extension - the degree of PGN violence the country experiences.

There are, however, inherent problems with relying on PGNs, including incompatibility of goals between the government and the group, or creating the possibility of agency loss (Carey et al., 2015; Mitchell et al., 2014). Moreover, once militias have been initiated by the state, they have a staying power, and may even fight the government if it tries to scale back their operations because they not align with its strategic goals (Ahram, 2011; Aliyev, 2016). In normal times, PGNs often operate where formal governance is low either because the regime cannot or does not want to be present in these regions (Mitchell et al., 2014; Aliyev, 2016). Accordingly, if COVID-19 is impacting the ability of the state to operate effectively, militias can fill this gap, although the impact will often be negative for the government over the long-term. Indeed, due to its sudden onset and comprehensive and overwhelming impact, the COVID-19 outbreak might be particularly illustrative of these trends. For instance, in Iraq, COVID-19 has undermined 'the fledgling government's legitimacy, as militias have stepped in to supply medical and humanitarian services' (Bussemaker, 2020). 
Importantly, the motivations of PGNs' to engage in violence can be combined into two broad categories: reactive and preemptive engagements. The first engagement type, reactive, refers to situations where PGNs react to increases in rebel attacks due to retraction of formal governance and military activity as a result of the pandemic. From this perspective, PGNs serve as direct substitutes for the formal state, engaging in combat to protect pro-government enclaves and populations from rebels. This is the case if hypothesis $\mathrm{H} 1$ (derived above) is correct, as the government relies on PGNs, due to the reasons discussed above, to stave off rebel attacks. Here, especially as PGNs are often more violent than regular forces (Mitchell et al., 2014; Koren, 2017; Ahram, 2011), the retraction of formal governments should lead to a higher incidence of violent conflict involving PGNs due to the corresponding increase in rebel activity.

The preemptive engagements category refers to increases in PGN activity that occur before rebels actually increase their levels of attacks. As we discussed above, it is possible that - at least in the short term - rebel activity may actually decrease due to different reasons. Just as declines in formal state activities open doors for rebels to challenge the state, declines in rebel activity and military capacity due to the pandemic can open doors for the state to root out the rebels. However, as the state is dealing with its own local governance and military capacity problems, it may 'contract' these preemptive attacks against the weakened rebels to PGNs.

The preemptive motivation is agnostic to whether hypothesis $\mathrm{H} 1$ is true or not. Anticipating or being informed by the state about an impeding governance vacuum and the potential for rebel violence, PGNs may increase their rates of attacks in an effort to squash any potentials for rebels to gain territory. In doing so, PGNs are able not only to weaken the rebels, but also establish themselves as invaluable ally to the state, thereby increasing potential revenues and resource support from the latter. As we discuss in detail below, this seems to be what happened in Nigeria 
as COVID-19 began spreading. These PGNs' moves essentially become preemptive because they fear what rebels can do with the opportunity.

In both the reactive and preemptive cases, PGNs substitute for government capacity, but their motivations for action are inherently different. However, because the preemptive motivation is agnostic as to whether hypothesis $\mathrm{H} 1$ is true or not, we derive hypothesis $\mathrm{H} 2$ independently of whether $\mathrm{H} 1$ gets empirical confirmation, as follows:

H2: As COVID-19 spreads the number of attacks by PGNs will be higher compared with pre-pandemic levels.

\section{Empirical Analysis}

Comparative analyses are useful for evaluating the viability of our hypotheses globally and over time. However, specific cases may exhibit more complex relationships between the dependent and independent variables of interest while data limitations might prevent us from making a causal claim with regard to any effect. To account for these issues, we test our hypotheses using a combined quantitative-qualitative methodology, which relies on statistical analysis of a global sample and a detailed evaluation of two key cases illustrating changes in the activity levels of each type of nonstate actor and illustrating the underlying mechanisms.

\section{Cross-National Analysis}

We test our hypotheses statistically on a sample encompassing 167 days (1 January to 15 June 2020) in 127 states, ${ }^{1}$ which correspond to the availability of data on conflict and COVID-19 death

\footnotetext{
${ }^{1}$ A list of the countries analyzed is reported in Table A2, Supplemental Appendix.
} 
estimates (as defined below). Our unit of analysis is hence the country-day, although in the Supplemental Appendix we report different models at the (higher) country-week and countrymonth levels of aggregation.

Data on attacks by rebels and PGNs were obtained from the Armed Conflict Location Events Dataset (ACLED), which relies on reports by non-governmental organizations (NGOs) and the media to code information on political violence incidents (Raleigh et al., 2010). ACLED includes a broad spectrum of dyadic interactions incorporating numerous types of violence, including the type of actor perpetrating the violence, measured according to location and date. These data hence match our country-day framework, thus ensuring our models capture a sufficiently high number of heterogeneous conflict events by the exact actor type who perpetrated them. However, to effectively test our hypotheses, the dependent variables must not only account for conflict intensification, but also ensure that - considering the limitations on our temporal period of interest (which can only go back as far as the origins of COVID-19) - such intensification constitutes a trend unique to 2020. It may be that, although conflict intensifies after COVID-19 begins to spread (especially after late March 2020), this trend is unrelated to COVID-19 and may occur, for instance, because warfare simply becomes more common in springtime.

Accordingly, we operationalize our dependent variables in two steps. We begin by retaining only conflict events (namely incidents coded by ACLED as direct attacks on armed actors, remote attacks such as IEDs, and violence perpetrated against civilians) related to our actors of interest: (i) incidents initiated by rebels, and (ii) incidents initiated by PGNs. In the next step we ensure that any changes in conflict trends, due to COVID-19 or otherwise, constitute a trend that is unique to 2020 , by subtracting the number of attacks by each actor type in a given day from the number of attacks the same day in 2019. Each of our two dependent variables $-\Delta$ Rebel 
attacksit $_{i t}$ and $\triangle P G N$ attacks $_{i t}$ - hence captures the annual change in the number of attacks by each actor type, with a mean and range of -0.095 and $-98 \Leftrightarrow 39$, and -0.089 and $-37 \Leftrightarrow 17$, respectively.

Descriptively, 35 and 37 countries within our sample experienced rebel attacks in 2020 and 2019, respectively; and 96 and 99 experienced PGN attacks in 2020 and 2019, respectively. For illustration of the average geographic distribution of each indicator globally, Figures A1-A2, Supplemental Appendix map the collapsed values for each variable by country. Additionally, as Figures A3-A4, Supplemental Appendix show, the data on both indicators is normally distributed, even when zero-change incidences are removed. When zero-change incidences are removed, the mean and median of $\Delta$ Rebel attacks $_{i t}$ are 34.12 and 5, respectively; for $\triangle P G N$ attacks $_{i t}$, the mean and median when zero-change incidences are removed are 89.25 and 11.5 , respectively.

To code our main independent variable, which measures the impact of COVID-19 in each country at the daily level, we rely on information on the number of COVID-19 deaths (per million people) from each country collected by the World Health Organization (WHO). We chose to use the number of deaths rather than the number of cases because of the larger error of measurements caused by variability of testing across and within states. In contrast to COVID-19 cases, deaths from COVID-19 must be recorded with the virus or antibody present in the body. To account for some lagging that may occur between the spread of the pandemic and its effects on conflict, we lag this variable by one day $(t-1)$. We therefore use deaths from COVID-19 to operationalize our main independent variable, COVID-19 deathsit-1, as the count of deaths from the pandemic (per million people) within a given country the previous day. Considering the range on this variable (0 $\Leftrightarrow 220.82$ ), we logged it prior to entering it into our model. It is important to emphasize that even information on COVID-19 deaths might still suffer from reporting bias. For example, some (authoritarian) regimes might exclude a-typical pneumonia and other probable cases of COVID 
from the daily death counts, meaning such estimates likely under-report pandemic casualties in a potentially non-random way. Partly, the reliance on country fixed effects should account for such across-context biases, ensuring that only within-country variations are analyzed. We also estimate several robustness models addressing some sources of this potential bias (e.g., in Tables A5 and A8, Supplemental Appendix).

Considering our data structure and building on Angrist and Pischke (2008), our identification strategy is as follows:

$$
y_{i t}=\beta_{0}+\beta 1 \ln c_{i t-1}+\beta_{2} y_{i t-1}+\beta_{3} \tau_{t}+\psi_{i}+\varphi_{m}+\varepsilon_{i}
$$

Where $y_{i t}$ is a vector of annual change in conflict events by rebels or PGNs in a given country $i$ during day $t$, and $\boldsymbol{y}_{\boldsymbol{i t}-1}$ the dependent variable lags (and $\beta_{2}$ its coefficient); $\ln \boldsymbol{c}_{\boldsymbol{i t}-1}$ is a vector of (logged) lagged daily coronavirus deaths per million people in a given country and $\beta_{1}$ its coefficient; $\boldsymbol{\tau}_{t}$ is the time trend accounting for changes in conflict that are constant over time and $\beta_{3}$ its coefficient; $\psi_{i}$ are fixed effects by country to account for all country-constant features; ${ }^{2} \boldsymbol{\varphi}_{\boldsymbol{m}}$ are fixed effects by month to account for seasonal trends; and $\varepsilon_{i}$ are standard errors clustered by country to account for heterogeneities over time. Considering that our dependent variables are continuous, unbounded from below or above, and (as Figures A3-A4, Supplemental Appendix illustrate) normally distributed, we rely on ordinary least squares to estimate the effect of COVID19 on annual change in conflict. Summary statistics of all variables are reported in Table A1, Supplemental Appendix.

Table 1 reports the results of our analysis of each hypothesis on a country-day sample. Interestingly, the results lend support only to hypothesis H2: the coefficient of COVID-19 deaths $s_{\text {it- }}$

\footnotetext{
${ }^{2}$ This fixed effects also serve as an alternative for control variables, considering the annual nature and lack of availability of such variables (which are measured annually for 2020), and their high levels of missingness, as we discuss in detail in the Supplemental Appendix. We nevertheless report a robustness model that includes a large number of controls in Table A3, Supplemental Appendix.
} 
$I$ is positive and highly-statistically significant (to the $1 \%$ level), suggesting that COVID-19 incidence indeed increased the frequency of attacks by PGNs compared with last year (2019). For illustration, in substantive terms, an increase of 10 deaths per million from COVID-19 will generate an expected 0.13 increase in the number of PGN attacks, compared with last year. Considering that the average annual change in PGN attacks during our period of interest is -0.08 , this is a substantive increase.

In contrast, we do not find a similarly strong relationship with respect to attacks by rebels; while the coefficient is positive, it is very small, and is not statistically significant according to any traditional thresholds. This, of course, does not mean COVID-19 will not have any effect on rebellions and insurgencies - as time goes by and the pandemic continues to spread, it may exert stronger effects on rebel group behaviors in conflict torn states - but for now we do not find support for this trend in the data. Nevertheless, that we find support for $\mathrm{H} 2$ but not $\mathrm{H} 1$ might suggest more support for the preemptive PGN attack logic we discussed in the previous section. Indeed, the results are robust to potential confounders, operationalization choices, and endogeneity and serial correlations, as illustrated by a battery of additional models estimated, reported, and discussed in the Supplemental Appendix (Tables A3-A10). Crucially, these sensitivity analyses confirm hypothesis $\mathrm{H} 2$ in every case and in some models, Hypothesis H1. 
Table 1: Determinants of Nonstate Actor Attacks.

\begin{tabular}{|c|c|c|}
\hline & $\Delta$ rebel attacks $_{\text {it }}$ & $\Delta P G N$ attacks $_{i t}$ \\
\hline Covid-19 deaths $s_{i t-1}{ }^{1}$ & $\begin{array}{c}0.012 \\
(0.021)\end{array}$ & $\begin{array}{c}0.054^{* * *} \\
(0.018)\end{array}$ \\
\hline$D V_{i t-1}$ & $\begin{array}{c}0.450^{* * *} \\
(0.006)\end{array}$ & $\begin{array}{r}0.189^{* * *} \\
(0.007)\end{array}$ \\
\hline$\tau_{t}$ & $\begin{array}{c}0.001 \\
(0.002)\end{array}$ & $\begin{array}{l}-0.001 \\
(0.001)\end{array}$ \\
\hline Observations & \multicolumn{2}{|c|}{21,209} \\
\hline & 0.313 & 0.187 \\
\hline Adjusted $\mathrm{R}^{2}$ & 0.309 & 0.182 \\
\hline
\end{tabular}

${ }^{*} \mathrm{p}<0.1 ;{ }^{* *} \mathrm{p}<0.05 ;{ }^{* * *} \mathrm{p}<0.01$

Variable coefficients are reported with standard errors clustered by country in parentheses. Fixed effects by country and month are included in each model although none is reported here.

1 Natural log.

\section{Case-Based Evidence: Afghanistan and Nigeria}

Overall, the quantitative analysis of our global country-day sample confirms our theoretical expectations regarding the role of PGNs, although not necessarily for rebel groups. To determine the generalizability of these findings to other world regions and identify more nuanced relationships, we conduct two short case studies of conflict-afflicted states: Afghanistan and Nigeria. Our decision to study these two specific countries relies on the "typical" case selection approach advocated by Seawright and Gerring, whereby an effective analysis "focuses on a case that exemplifies a stable, cross-case relationship...in which the evidence at hand (in the case) is judged according to whether it validates the stipulated causal mechanisms or not" $(2008,299)$. Importantly, the focus on Afghanistan and Nigeria as our cases allows us to account for the degree of political openness (both states are authoritarian presidential republics, but suffer from widespread political corruption) and the presence of conflict and rebel groups (both states suffer from endemic 
conflict by small rebel groups, and both involve some PGN activity). Detailed background discussion on each context is reported in the Supplemental Appendix.

\section{The Taliban and PGNs in Afghanistan}

The current conflict in Afghanistan began in 2001 but follows a series of conflicts that started in the late 1970s. During the 1990s, the Taliban gained a significant portion of Afghanistan's territory and established an Islamic rule of law in the country. The US-led invasion of Afghanistan quickly pushed out the Taliban and established a new US-supported Afghani government, but the government remains weak to the present day and heavily relies on US support for its strength and legitimacy as well as PGNs for fighting the Taliban in more inhospitable terrain. Despite the establishment of a non-Taliban-led government, the Taliban continues to be active in much of the country and is in full control of between 10 and 15 districts (see Figure A5, Supplemental Appendix for a map of areas under Taliban control).

The Taliban's attacks on health facilities and health workers have gotten the attention of the UN, who recently made a plea for the Taliban to cease their attacks while the pandemic sweeps through the country even though the Taliban was initially deeply involved in pandemic relief efforts (UN, 2020). When COVID-19 began to spread, the Taliban, at least temporarily, reduced its conflict activities, and was actively working with the US and the Afghanistan government to create a peace agreement (USSD, 2020; The Economist, 2020). Instead of maintaining this peaceful trajectory, the group has used the power vacuum created by COVID-19 to build up its support base and reputation among local civilians. To this end, the Taliban initially helped civilians with pandemic relief, for instance, by initiating public information campaigns, distributing goods, and enforcing quarantine measures. Many Afghani hospitals and clinics are continually at a limited 
capacity, and numerous Afghanis do not have access to a hospital because it has been closed, destroyed, or never existed in the first place (Karim and Alimi, 2020). Knowing this, the Taliban has actively moved into towns and cities without a hospital to provide pandemic relief to help mitigate the spread of COVID-19 (Rasheed et al., 2020; The Economist, 2020).

Another reason that the group may have reduced its violent operations relates to the impact COVID-19 had on its own structure and capacities. Despite these COVID-19 relief efforts, many of the Taliban's top leadership, including its supreme leader, have contracted the virus, initiating a very sudden change in the governance structures (O'Donnell, 2020). While it is unclear whether this change in leadership will have long-term effects, the Afghani government's incapable response has allowed the group to leverage the pandemic for its own gain. Perhaps as a result, it does appear that, at least in Afghanistan, COVID-19 did not have an insurgency-intensifying effect during the first few months of the pandemic.

With the global spread of COVID-19 and the US government having to focus efforts on its own COVID-19 relief, the already weak Afghani government has become even weaker (O’Donnell, 2020). It normally relies heavily on the US for guidance and assistance and now that the US has turned its attention inward, the Afghani government has struggled to maintain the weak hold it had (Feroz \& Zaman, 2020). With the government's primary sponsor withdrawing its support, other governments are also being less attentive, leaving Afghanistan to fight both COVID19 and the Taliban on its own.

To at least partly compensated for this weakness, and as suggested by our theory, the government has relied on the help of some PGNs, but these groups have been notoriously unreliable and violent even before the pandemic (Badalič, 2019; Al Jazeera, 2019). The government's reliance on PGNs has adversely affected not only the regime's military capacity but 
also - due to the violent nature of most of these groups and the fact that many militia members often defect to the Taliban (Derksen, 2017) - its relationship with civilians. This has often left the government worse off, and servs as a telling evidence of the potential long-term governance impacts of COVID-19 via the PGN pathway we hypothesized. Indeed, the rapid spread of COVID19 through Afghani military forces has further weakened an already weak military, intensifying these PGN-related problems and the government's need to rely on these groups (Gul, 2020).

It is important to emphasize that despite providing relief efforts and having to deal with COVID-19 effects within the group, the Taliban has re-intensified its attacks on the government (O’Donnell, 2020; Rasheed et al., 2020). Although a February 2020 peace agreement looked promising (as we discuss in the Supplemental Appendix), by providing the Taliban with the ability to take advantage of the government's focus on pandemic response and its weakened military, COVID-19 has empowered the group further with respect to the government (Feroz \& Zaman, 2020). The disease has also given the Taliban the opportunity to exploit an already weak state and regain some of their lost territory and control. Using a system of pacification followed by violence, they have been able to exploit the pandemic for their gain, although it is important to note that this pattern of aiding and then attacking is a characteristic tactic used by the Taliban (Feroz \& Zaman, 2020; Jackson, 2020; Kapur \& Saxena, 2020, Marx et al., 2020).

Figure 1 - which plots $\triangle$ Rebel attacks $_{i t}$ (left) and $\triangle P G N$ attacks $_{i t}$ (right) values for Afghanistan over the 1 January 2020 to 15 June 2020 period - lends some support to these patterns. For rebels, the figure shows that over the period, violence has consistently stayed below its 2019 levels, as illustrated by the fact that the trend-line (which plots the smoothed average in nonparametric terms with 95 percent confidence intervals) never goes above zero, suggesting an overall pacifying effect of COVID-19 on violent insurgent activity in 
Afghanistan, which is generally lower than last year. The figure also suggests that Taliban attacks may be resuming their 2019 level, as shown by the fact that rebel violence pushes to the zero line by the end of the period. Nevertheless, in line with the qualitative evidence discussed above, the data do not lend support to hypothesis $\mathrm{H} 1$ and suggest that the pandemic did not have, overall, an intensifying effect on Taliban violence, compared with last year's levels, at least as of yet. For comparison, while the left subfigure does not provide clear support for hypothesis H2 - PGN attacks seemed to have also decreased somewhat as COVID-19 began to spread (compared with 2019) - it does suggest by June 2020 these attacks have already acceded their June 2019 level.

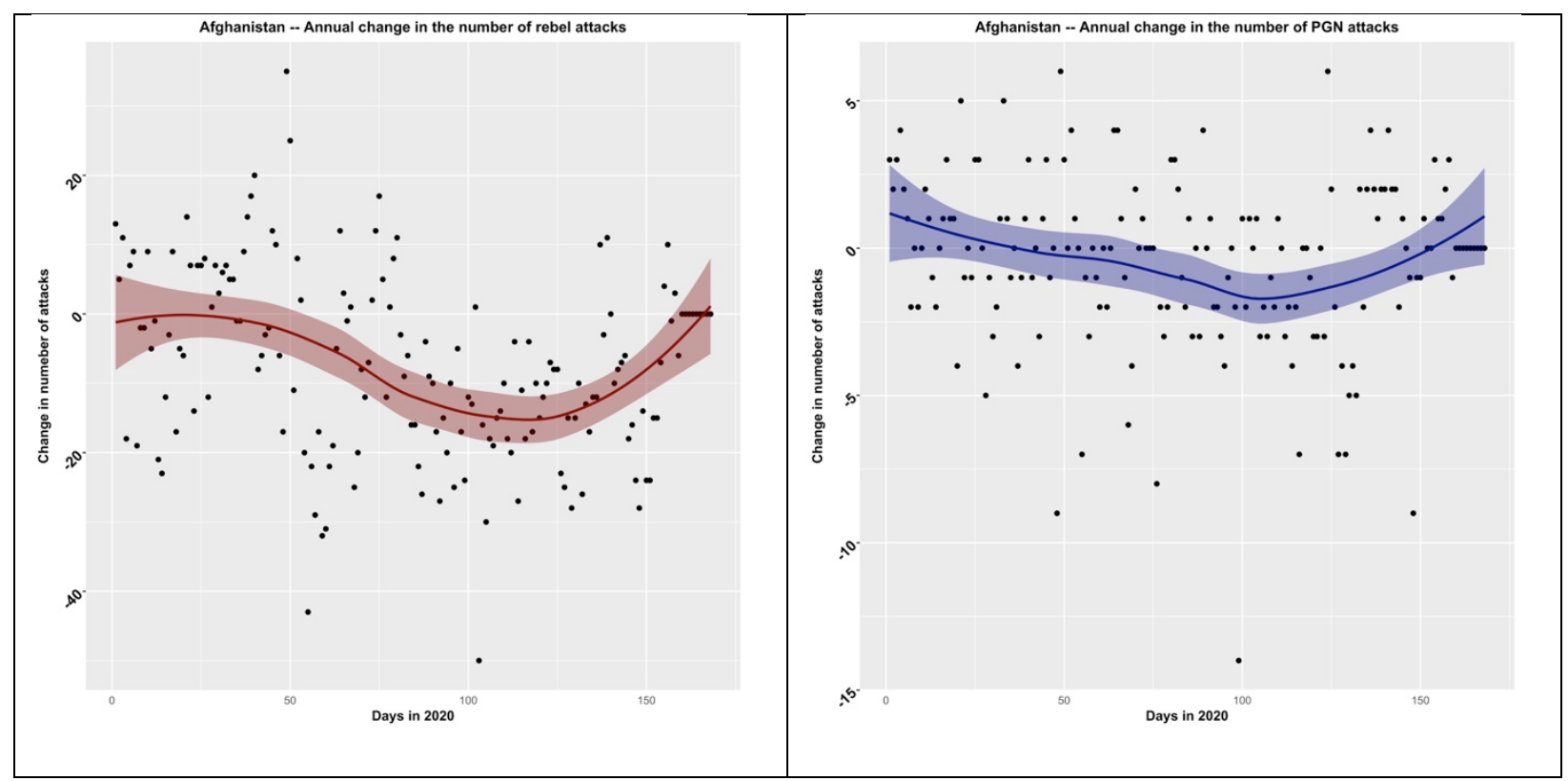

Figure 1: (Left) $\triangle$ Rebel attacksit and (Right) $\triangle P G N$ attacks ${ }_{i t}$ values for Afghanistan, 1 January 2020 to 15 June 2020 .

\section{Boko Haram and Pro-Government Militias in Nigeria}

Boko Haram (BH), officially The People Committed to the Propagation of the Prophet's Teachings and Jihad, is an extremist group that began its insurgency against the Nigerian government in 2009. 
Building on support from al-Qaeda and al-Shabaab, $\mathrm{BH}$ was able to gain significant territory in a relatively short time frame with the ultimate aim of establishing an Islamic state. Known for its extremely violent tactics and brutal attacks on civilians, $\mathrm{BH}$ seized large swaths of northeastern Nigeria, but were eventually stymied by a coalition of forces from Nigeria and surrounding states. The Nigerian state is under a lot of pressure from human rights organizations and the international community to defeat Boko Haram, but limited resources and Boko Haram's foreign support have made this difficult. As a result, the government, even before the pandemic the government has become increasingly reliant on militias to do much of the fighting against Boko Haram.

COVID-19 has intensified these pressures, forcing the government to focus on pandemic relief and economic stability while simultaneously fighting BH (Campbell, 2020a; Maclean, 2020). Given the sudden slackness in offensive and defensive measures, BH has focused its attacks since March 2020 on smaller, less defended towns and cities on the border between Nigeria and Cameroon (Kishor, 2020). The group has also released statements that COVID-19 measures put in place by the Nigerian government are an attack on Islam and many top leaders within the group are not taking proper safety precautions (Campbell, 2020b). These lax precautions have also caused COVID-19 to spread rapidly through the ranks of Boko Haram, potentially weakening the group but also further instigating it to conduct attacks (Bukarti, 2020).

Responding to both the supposed increases in rate of $\mathrm{BH}$ attacks and to potential further intensification, several militia groups, many of whom had been working with government in the have similarly intensified their actions against the group (Felbab-Brown, 2020b). The government's reliance on militias has increased substantively since the Nigerian military has experienced infighting and high turnover of its leadership. Here, the cost-saving benefits of PGNs we discussed in the theory section were important - militias cost less money and require less 
training than official military forces, which prompted the government to rely on them as an alternative even before the pandemic.

As soon as the government started shifting its focus to pandemic mitigation, PGNs, particularly these anti-BH groups, began preparing their defenses in anticipation of increased attacks (Felbab-Brown, 2020a), supporting not only the reactive but also the preemptive logic we discussed in the theory section. Indeed, although these groups were initially ready to act as a defense mechanism while the government was dealing with COVID-19, these groups have gradually moved on the offensive over the summer of 2020 (Agbiboa, 2020, Felbab-Brown, 2020a). Moreover, responding to the original increase in BH attack in March 2020, these PGNs have started taking more drastic action, intensifying the number of and the degree of violence using in their retaliatory attacks (Campbell, 2020c; Felbab-Brown, 2020a).

As suggested by our theory, both rebels (BH) and PGNs such the Civilian Joint Task Force (CJTF) and the Vigilante Group of Nigeria (VGN) have taken advantage of the power vacuum engendered by COVID-19 and increased their violence within these opening governance spaces, knowing the government is heavily focused on pandemic relief and does not have the resources to get heavily actively involved (Bukarti, 2020; Dixit \& Onwujekwe, 2020; Felbab-Brown, 2020b; Ikelegbe, 2005). But while $\mathrm{BH}$, a rebel groups, is using the pandemic to try and gain territory and supporters, PGNs are using the pandemic to both defend against and to preempt attacks by BH. It seems that at least part of the reason behind the intensification of preemptive PGN attacks us that these groups hope to become more central actors in the government's apparatus after COVID-19 and its impacts have passed, prompting them to further their own goals while also attempting to stymie BH (Bukarti, 2020b). The evidence does suggest that pro- and anti-government groups have taken advantage of the government's focus on pandemic relief to further their own goals while 
also attempting to stymie the other groups, but also that PGNs have been actually more agreessive in these attempts (Bukarti, 2020a).

For illustration, Figure 2, which (again) plots $\Delta$ Rebel attacks $_{i t}$ (left) and $\triangle P G N$ attacks $i t$ (right) values for Nigeria over the 1 January 2020 to 15 June 2020 period, lends support to the pattern elucidated by this qualitative evidence. Specifically, the right subfigure illustrates that PGN attacks strongly (and differently from zero) increase as COVID-19 spreads throughout Nigeria compared with their 2019 levels, which provides additional confirmation of the qualitative evidence discussion above, and hypothesis $\mathrm{H} 2$ broadly. In contrast, the left subfigure shows that rebel attacks remain relatively unchanged (with a possible slight and significant increase around April) compared with their 2019 levels, which, again, does not support hypothesis H1. Overall, then, the qualitative evidence discussed above the and the data plotted in Figure 2 confirm the statistical results presented in Table 1 and illustrate the viability of our hypothesized theoretical mechanisms.

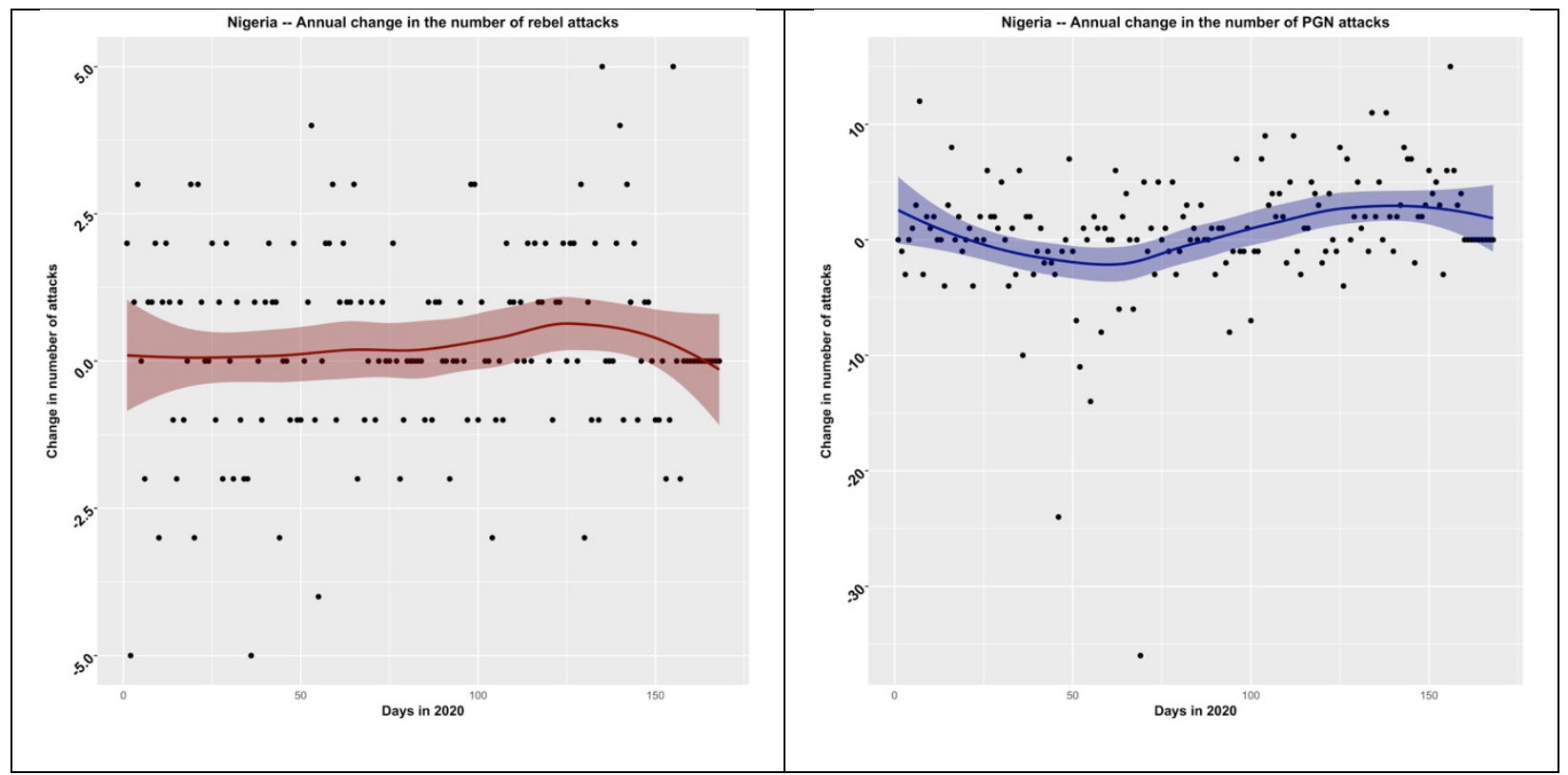

Figure 2: (Left) $\triangle$ Rebel attacks $i$ and (Right) $\triangle P G N$ attacks $_{i t}$ values for Nigeria, 1 January 2020 to 15 June 2020 . 


\section{$\underline{\text { Scope Conditions }}$}

Our central question is whether the spread of COVID-19 has shaped violence trends by rebels and pro-state armed groups. It is also important to acknowledge some potential limitations of this study. First, we focused on violent outcomes specifically. We stipulated above our reasons for doing so, including the fact that violent and nonviolent outcomes can occur simultaneously and the greater importance of violent outcomes compared with nonviolent outcomes for academics and policymakers. However, the possibility that the spread of COVID-19 has also reduced violence in some contexts and any confounding effects therein should be acknowledged (we discussed some potential explanations above).

Second, as we discussed in our theoretical section, a variety of mechanisms may underlie the empirically observed relationships between the spread of COVID-19 on the one hand, and violence by either rebels or PGNs. It is also possible that COVID-19 has affected mobilization via other pathways, not expressly discussed above, or that its effects have varied based on rebel or PGN centric attributes - their leadership, structure, etc. While, considering the exogeneity of COVID-19 deaths to conflict and the identification strategy employed in equation 1, our results especially the GMM robustness models reported in Tables A4 and A7, Supplemental Appendix are consistent with a causal interpretation, they do not verify any of the causal mechanism(s) at work. We recognize that there are different pathways that might lead to observed relationship, and we believe that future work could focus more specifically on comparing and validating the different particular mechanism at work.

\section{Conclusion}


Violence by nonstate actors has been rising in recent decades. According to ACLED, 33\% of the attacks identified between 1 January 2020 and 15 June 2020 were perpetrated by the state, while $42.3 \%$ were perpetrated by pro- and anti-government nonstate actors (Raleigh et al., 2010). Our analysis suggests that COVID-19 has increased the risk of such violence, at least among pro-government nonstate actors. As such, our findings have implications for both scholars and policymakers.

First, we expand on past studies that associated the spread of disease with violence by rebels (e.g., Bagozzi, 2016; Cervellati et al., 2017; Kustra, 2017; Ostergard, 2004). by linking - both theoretically and empirically - pandemics to violence by pro-government groups. Future research will therefore benefit from taking the role of pandemics on civil war and political violence into account. One effective direction is to examine how pandemics moderate or reinforce the effects of other environmental disasters, such as earthquakes or droughts, on ongoing wars. Another relevant trajectory is to analyze if pandemic prevalence increases the frequencies of violence against civilians during civil war. Scholars will also benefit from examining the exact pathways by which pandemics can increase the risk of war, e.g., through theorizing on and modeling their impacts through socioeconomic factors such as reducing GDP and development levels.

For policymakers, our findings highlight the contexts where conflict intensification may become more likely - namely, where sudden pandemic shocks push governments to rely more on PGNs (militias, paramilitaries, auxiliaries) - and identify potential high-risk cases. They also illustrate the advantages of adding pandemics to quantitative and qualitative models of conflict and mass killing forecasting. In increasing instability and reducing state strength, pandemics open the door for violent behaviors by groups seeking to 
replace the state. As such, pandemic prevalence - especially where there are already active PGNs - serves as a threat multiplier, and highlights where and when intervention and aid should be directed. 


\section{References}

Agbiboa, D. E. (2020). The Precariousness of Protection: Civilian Defense Groups Countering Boko Haram in Northeastern Nigeria. African Studies Review, 64(1).

Ahram, A. I. (2011). Proxy Warriors: The Rise and Fall of State Sponsored Militias. Palo Alto: Stanford University Press.

Al Jazeera (2019, April 24). UN: Pro-government forces killed more Afghans than armed groups. https://www.aljazeera.com/news/2019/4/24/un-pro-government-forces-killedmore-afghans-than-armed-groups.

Aliyev, H. (2016). Strong militias, weak states and armed violence: Towards a theory of 'stateparallel' paramilitaries. Security dialogue, 47(6), 498-516.

Angrist, J. D., \& Pischke, J. S. (2008). Mostly harmless econometrics: An empiricist's companion. Princeton university press.

Assburg, M., Azizi, H., Dalay, G., and Pieper, M. 2020. “The COVID-19 Pandemic and Conflict Dynamics in Syria.” SWP Comment 2020/C 21, May 2020. https://www.swpberlin.org/10.18449/2020C21/.

Ataguba, J. E. (2020). COVID-19 pandemic, a war to be won: understanding its economic implications for Africa.

Badalič, V. (2019). Militias We Trust: Civilian Victims of Targeted Killings by Pro-government Armed Groups in Afghanistan. In The War Against Civilians. Palgrave MacMillan.

Bagozzi, B. E. (2016). On malaria and the duration of civil war. Journal of conflict resolution, 60(5), 813-839.

Bagozzi, B. E., \& Koren, O. (2021). The Diplomatic Burden of Pandemics: Lessons from Malaria. Accepted at Political Science Research and Methods. 
Bagozzi, B. E., Koren, O., \& Mukherjee, B. (2017). Droughts, land appropriation, and rebel violence in the developing world. The journal of politics, 79(3), 1057-1072.

Berariu, R., Fikar, C., Gronalt, M., \& Hirsch, P. (2015). Understanding the impact of cascade effects of natural disasters on disaster relief operations. International Journal of Disaster Risk Reduction, 12, 350-356. https://doi.org/10.1016/j.ijdrr.2015.03.005

Bellemare, M. F. (2015). Rising food prices, food price volatility, and social unrest. American journal of agricultural economics, 97(1), 1-21.

Bukarti, B. (2020a). 'A deadly alliance: coronavirus makes Boko Haram more dangerous than ever.' The Telegraph 7 June 2020. https://www.telegraph.co.uk/global-health/scienceand-disease/deadly-alliance-coronavirus-makes-boko-haram-dangerous-ever/

Bukarti, B. (2020b, May 20). How Is Boko Haram Responding to COVID-19? Institute for Global Change. https://institute.global/policy/how-boko-haram-responding-COVID-19

Bussemaker, N. (2020). 'Iraq's New Government: What to Know.' Council on Foreign Relations 11 August 2020. https://www.cfr.org/in-brief/iraqs-new-government-what-know.

Campbell, J. (2020a, April 3). How Jihadi Groups in Africa Will Exploit COVID-19. Council on Foreign Relations. https://www.cfr.org/blog/how-jihadi-groups-africa-will-exploitCOVID-19.

Campbell, J. (2020b, April 17). Boko Haram's Shekau Labels Anti-COVID-19 Measures an Attack on Islam in Nigeria. Council on Foreign Relations. https://www.cfr.org/blog/bokoharams-shekau-labels-anti-COVID-19-measures-attack-islam-nigeria

Campbell, J. (2020c, June 11). Beyond the Pandemic, Boko Haram Looms Large in Nigeria. Council on Foreign Relations. https://www.cfr.org/in-brief/beyond-pandemic-bokoharam-looms-large-nigeria 
Carey, S. C., Colaresi, M. P., \& Mitchell, N. J. (2015). 'Governments, informal links to militias, and accountability.' Journal of Conflict Resolution, 59(5), 850-876.

Cervellati, M., Sunde, U., \& Valmori, S. (2017). Pathogens, weather shocks and civil conflicts. The economic journal, 127(607), 2581-2616.

Chattu, V. K., \& Knight, W. A. (2019). Global Health Diplomacy as a Tool of Peace. Peace Review, 31(2), 148-157. https://doi.org/10.1080/10402659.2019.1667563.

Cunningham, K. G., \& Loyle, C. E. (2020). Introduction to the Special Feature on Dynamic Processes of Rebel Governance. Journal of conflict resolution.

Dauvergne, P. (1998). The Political Economy of Indonesia’s 1997 Forest Fires. Australian Journal of International Affairs, 52(1), 17.

Davies, S. E. (2013). National security and pandemics. UN chronicle, 50(2), 20-24.

De Lauri, A., \& Suhrke, A. (2020). Armed governance: the case of the CIA-supported Afghan militias. Small wars \& insurgencies.

Derksen, D. (2017). In Afghanistan, Today's Pro-Government Militias Could be Tomorrow's Insurgents. War on the Rocks 11 December 2017. https://warontherocks.com/2017/12/afghanistan-todays-pro-government-militiastomorrows-insurgents/.

Dirkz, T. (2017). The Unintended Consequences of US Support on Militia Governance in Kunduz Province, Afghanistan. Civil wars, 19(3), 377-401.

Dixit, S., Ogundeji, Y. K., \& Onwujekwe, O. (2020, July 2). How well has Nigeria responded to COVID-19? Brookings. https://www.brookings.edu/blog/futuredevelopment/2020/07/02/how-well-has-nigeria-responded-to-COVID-19/. 
Döring, S. (2020). 'Come rain, or come wells: How access to groundwater affects communal violence.' Political Geography, 76, 102073.

Eastin, J. (2016). Fuel to the Fire: Natural Disasters and the Duration of Civil Conflict. International Interactions, 42(2), 29.

The Economist. (2020, May 7). The Taliban are joining Afghanistan's fight against COVID-19. https://www.economist.com/asia/2020/05/09/the-taliban-are-joining-afghanistans-fightagainst-COVID-19

The Economist. (2019, May 30). Jair Bolsonaro will not defeat crime in Brazil by tolerating militias. https://www.economist.com/leaders/2019/05/30/jair-bolsonaro-will-not-defeatcrime-in-brazil-by-tolerating-militias

Elbe, S. (2002). HIV/AIDS and the Changing Landscape of War in Africa. International security, 27(2), 159-177.

Elbe, S. (2005). AIDS, security, biopolitics. International relations, 19(4), 403-419.

Enemark, C. (2017). Ebola, disease-control, and the Security Council: from securitization to securing circulation. Journal of global security studies, 2(2), 137-149.

Fearon, J. D., \& Laitin, D. D. (2003). Ethnicity, insurgency, and civil war. American political science review, 97(1), 75-90.

Fearon, J. D. (2008). Economic development, insurgency, and civil war. Institutions and economic performance, 292, 328.

Felbab-Brown, V. (2020a, April 15). Militias (and militancy) in Nigeria's north-east: Not going away. Brookings. https://www.brookings.edu/research/militias-and-militancy-in-nigeriasnorth-east-not-going-away/. 
Felbab-Brown, V. (2020b, April 21). As conflict intensifies in Nigeria's North East, so too does a reliance on troubled militias. Brookings. https://www.brookings.edu/blog/order-fromchaos/2020/04/21/as-conflict-intensifies-in-nigerias-north-east-so-too-does-a-reliance-ontroubled-militias/

Feroz, E., \& Zaman, M. (2020, April 16). Coronavirus in Afghanistan: The pandemic hasn't stopped the government and the Taliban from fighting. Vox. https://www.vox.com/COVID-19-coronavirus-world-internationalresponse/2020/4/16/21220611/coronavirus-afghanistan-war-taliban-COVID-19-casesdeaths

Gallup, J. L., \& Sachs, D. J. (2000). The Economic Burden of Malaria (working papers). Boston (MA): Center for International Development at Harvard University.

Gates, B. (2020, April 30). What you need to know about the COVID-19 vaccine. Gatesnotes.Com. https://www.gatesnotes.com/Health/What-you-need-to-know-about-the$\underline{\text { COVID-19-vaccine?WT.tsrc=BGEM }}$

Gul, A. (2020, May 5). COVID-19 Not Affecting Afghan Border Fencing, Pakistan Army Says. Voice of America. https://www.voanews.com/COVID-19-pandemic/COVID-19-notaffecting-afghan-border-fencing-pakistan-army-says.

Guterres, António. (2020). The fury of the virus illustrates the folly of war. Secretary-General of the United Nations, 23 March, 2020. https://www.un.org/en/un-coronaviruscommunications-team/fury-virus-illustrates-folly-war.

Hendrix, C. S. (2010). Measuring state capacity: Theoretical and empirical implications for the study of civil conflict. Journal of peace research, 47(3), 273-285.

Herbst, H. J. (2000) States and Power in Africa: Comparative Lessons in Authority and Control. 
Ide, T. (2016). Toward a constructivist understanding of socio-environmental conflicts. Civil wars, 18(1), 69-90.

Ikelegbe, A. (2005). State, Ethnic Militias, and Conflict in Nigeria. Canadian Journal of African Studies / Revue Canadienne Des Études Africaines, 39(3), 490-516.

Jackson, A. (2020, May 29). The Taliban Are Using Afghanistan's Coronavirus Pandemic for Propaganda. Foreign Policy. https://foreignpolicy.com/2020/05/06/taliban-afghanistancoronavirus-pandemic/

Jonkman, S.N. \& Kelman, I. (2005). An analysis of the causes and circumstances of flood disaster deaths. Disasters, 29(1), 75-97.

Kapur, R., \& Saxena, C. (2020, April 28). The Taliban makes the most of COVID-19 crisis in Afghanistan. The Interpreter. https://www.lowyinstitute.org/the-interpreter/talibanmakes-most-COVID-19-crisis-afghanistan

Karim, M. A., \& Alimi, M. (2020, June 8). Afghan Lives Through the Lens of COVID-19. The Diplomat. https://thediplomat.com/2020/06/afghan-lives-through-the-lens-of-COVID-19/

Kim, Y. (2018). Armed conflict, health spending, and HIV. The international journal of health planning and management, 33(3), 581-595.

Kishor, D. (2020, August 8). Terrorism and COVID-19: Brutality of Boko Haram in Africa. Modern Diplomacy. https://moderndiplomacy.eu/2020/08/09/terrorism-and-COVID-19brutality-of-boko-haram-in-africa/.

Koren, O., \& Sarbahi, A. K. (2018). State capacity, insurgency, and civil war: A disaggregated analysis. International Studies Quarterly, 62(2), 274-288.

Koren, O. (2017). Means to an end: Pro-government militias as a predictive indicator of strategic mass killing. Conflict management and peace science, 34(5), 461-484. 
Kustra, T. (2017). HIV/AIDS, life expectancy, and the opportunity cost model of civil war. Journal of conflict resolution, 61(10), 2130-2157.

Lin, T.-H. (2015). Governing Natural Disasters: State Capacity, Democracy, and Human Vulnerability. Social Forces, 93(3), 1267-1300. https://doi.org/10.1093/sf/sou104.

McLean, E. V., \& Whang, T. (2021). Economic Sanctions and Government Spending Adjustments: The Case of Disaster Preparedness. British Journal of Political Science, 51(1), 394-411. https://doi.org/10.1017/S0007123418000613.

Maclean, R. (2020, July 23). COVID-19 Outbreak in Nigeria Is Just One of Africa's Alarming Hot Spots. https://www.nytimes.com/2020/05/17/world/africa/coronavirus-kano-nigeriahotspot.html.

Martin, K. (2009). The Danger of Tribal Militias in Afghanistan: Learning from the British Empire. Journal of international affairs, 63(1), 157-174.

Marx, W., Yusufzai, M., Mengli, A., \& Holmes, A. (2020, May 23). Taliban leverages coronavirus crisis to burnish its image as violence in Afghanistan surges. NBC. https://www.nbcnews.com/news/world/taliban-leverages-coronavirus-crisis-burnish-itsimage-violence-afghanistan-surges-n1213096.

Mitchell, N. J., Carey, S. C., \& Butler, C. K. (2014). The impact of pro-government militias on human rights violations. International Interactions, 40(5), 812-836.

Nel, P., \& Righarts, M. (2008). Natural Disasters and the Risk of Violent Civil Conflict. International Studies Quarterly, 52(1), 159-185. https://doi.org/10.1111/j.14682478.2007.00495.x 
O’Donnell, L. (2020, June 1). Did the Coronavirus Kill the Taliban's Supreme Leader? Foreign Policy. https://foreignpolicy.com/2020/06/01/afghan-taliban-coronavirus-pandemicakhunzada/.

Ostergard, R. L. (2004). 'HIV/AIDS, the military and the future of Africa's security.' In ISA annual convention, Montreal, Canada, March 17-20, 2004. https://www.researchgate.net/profile/Robert_Ostergard_Jr/publication/255625208_HIVA IDS_The_Military_and_the_Future_of_Africa's_Security/links/543a53830cf2d6698be18 fe2/HIV-AIDS-The-Military-and-the-Future-of-Africas-Security.pdf.

Raleigh, C., \& Kishi, R. (2020). Hired guns: using pro-government militias for political competition. Terrorism and political violence, 32(3), 582-603.

Raleigh, C., Linke, A., Hegre, H., \& Karlsen, J. (2010). Introducing ACLED: an armed conflict location and event dataset: special data feature. Journal of peace research, 47(5), 651660.

Rasheed, Z., Alsaafin, L. \& Najjar, F. (2020, June 6). “Disaster” looms in coronavirus-hit Afghanistan: Live updates. News | Al Jazeera. https://www.aljazeera.com/news/2020/06/brazil-bolsonaro-threatens-exit-livecoronavirus-updates-200606002752178.html

Reinhardt, G. Y. \& A. D. Ross. (2015). Expanding Social Science Through Disaster Studies. Social Science Quarterly 100(7): 2523-2529.

Ruckstuhl, L., Lengeler, C., Moyen, J. M., Garro, H., \& Allan, R. (2017). Malaria case management by community health workers in the Central African Republic from 20092014: overcoming challenges of access and instability due to conflict. Malaria journal, 16(1), 388. 
Sawyer, D. (1993). Economic and social consequences of malaria in new colonization projects in Brazil. Social science \& medicine, 37(9), 1131-1136.

Seawright, J., \& Gerring, J. (2008). Case selection techniques in case study research: A menu of qualitative and quantitative options. Political research quarterly, 61(2), 294-308.

Shalizi, H. (2020, May 7). Exclusive: Large number of COVID-19 cases among Afghan medics spark alarm in Kabul. Reuters. https://www.reuters.com/article/us-health-coronavirusafghanistan-hospit/exclusive-large-number-of-COVID-19-cases-among-afghan-medicsspark-alarm-in-kabul-idUSKBN22J2PJ

Sharifi, S., \& Adamou, L. (2018, January 31). Taliban “threaten 70\% of Afghanistan.” BBC News. https://www.bbc.com/news/world-asia-42863116

Skocpol, T., Evans, P., \& Rueschemeyer, D. (1985). Bringing the state back in. New York: Cambridge.

The United States Army (U. S. Army). COVID-19 Latest Guidance: The United States Army. (2020). Retrieved from https://www.army.mil/coronavirus.

USSD. 2020. Agreement for Bringing Peace to Afghanistan between the Islamic Emirate of Afghanistan which is not recognized by the United States as a state and is known as the Taliban and the United States of America. [Peace Agreement]. https:/www.state.gov/wpcontent/uploads/2020/02/Agreement-For-Bringing-Peace-to-Afghanistan-02.29.20.pdf.

Von Uexkull, N., Croicu, M., Fjelde, H., \& Buhaug, H. (2016). Civil conflict sensitivity to growing-season drought. Proceedings of the National Academy of Sciences, 113(44), 12391-12396.

Wise, P. H., \& Barry, M. (2017). Civil war \& the global threat of pandemics. Doedalus, 146(4), 71-84. 
Supplemental Appendix For

\section{COVID-19, STATE CAPACITY, AND POLITICAL VIOLENCE BY NONSTATE ACTORS}

\section{Contents}

$\begin{array}{lr}\text { Summary Statistics and Figures } & 2\end{array}$

Summary statistics . . . . . . . . . . . . . . . . . . . 2

Histograms and maps . . . . . . . . . . . . . . . . . 4

$\begin{array}{lr}\text { Sensitivity Analyses } & 6\end{array}$

Case Studies: Additional Information $\quad 19$

Case selection discussion . . . . . . . . . . . . . . . . . . 19

Maps of Taliban control . . . . . . . . . . . . . . . . . . . . . 21

U.S.-Taliban 2020 agreement . . . . . . . . . . . . . . . . . . 23

$\begin{array}{ll}\text { References } & 24\end{array}$

This appendix includes three parts. In the first part we report summary statistics for our variables, as well as global maps and histograms showing the distribution of our dependent variables. In the second part we report a large set of sensitivity analyses designed to illustrate the robustness of our findings from the main paper. The third part include addition background information on our cases. 


\title{
Summary Statistics and Figures
}

\author{
Summary statistics
}

Table A1: Summary Statistics of All Variables, January 1 - June 15, 2020

\begin{tabular}{|c|c|c|c|c|c|}
\hline & Minimum & Median & Mean & $\operatorname{Max}$ & $\mathrm{SD}$ \\
\hline \multicolumn{6}{|l|}{ Day level data } \\
\hline$\overline{\Delta \text { rebel attacks }}$ it & -98 & 0 & -0.094 & 39 & 2.271 \\
\hline$\triangle P G N$ attacks $_{i t}$ & -37 & 0 & -0.087 & 17 & 1.759 \\
\hline Covid-19 deaths $s_{i t-1}^{1}$ & 0 & 0 & 0.606 & 5.396 & 1.074 \\
\hline$N T L(2014)_{i}{ }^{1}$ & 0.459 & 4.167 & 4.248 & 9.257 & 1.839 \\
\hline Population $(2011)_{i}{ }^{1}$ & 6.668 & 9.334 & 9.443 & 14.032 & 1.370 \\
\hline$G D P P C(2011)_{i}^{1}$ & 5.659 & 8.234 & 8.227 & 10.947 & 1.106 \\
\hline Military expenditure (2019) ${ }_{i}{ }^{1}$ & 0 & 1.872 & 1.906 & 3.490 & 0.601 \\
\hline Polity2 (2018) $i$ & -10 & 6 & 3.134 & 10 & 5.950 \\
\hline Oil rents, \% GDP (2017) ${ }_{i}$ & 0 & 0.05 & 3.075 & 37.782 & 7.867 \\
\hline Mountains $_{i}$ & 0 & 10.3 & 18.848 & 82.2 & 22.115 \\
\hline${\text { Ethnic } \text { fractionalization }_{i}}$ & 0.005 & 0.506 & 0.462 & 0.925 & 0.276 \\
\hline Religious fractionalization $_{i}$ & 0 & 0.351 & 0.365 & 0.783 & 0.211 \\
\hline N. rebel groups ${ }_{i}$ & 0 & 0 & 0.339 & 15 & 1.533 \\
\hline N. $P G N s_{i}$ & 0 & 1 & 4.276 & 66 & 9.360 \\
\hline Weekend $_{i t}$ & 0 & 0 & 0.287 & 1 & 0.453 \\
\hline \multicolumn{6}{|l|}{ Weelky level data } \\
\hline$\overline{\Delta \text { rebel attacks }}$ it & -213 & 0 & -0.643 & 113 & 10.111 \\
\hline$\triangle P G N$ attacks $_{i t}$ & -93 & 0 & -0.572 & 44 & 6.951 \\
\hline Covid-19 deaths ${ }_{i t-1}{ }^{1}$ & 0 & 0 & 1.093 & 7.250 & 1.682 \\
\hline
\end{tabular}

${ }^{1}$ Natural log 
Table A2: List of Countries Analyzed

\begin{tabular}{|c|c|c|c|}
\hline "Afghanistan" & "Albania" & "Algeria" & "Angola" \\
\hline "Antigua \& Barbuda" & "Argentina" & "Armenia" & "Azerbaijan" \\
\hline "Bahrain" & "Bangladesh" & "Barbados" & "Belarus" \\
\hline "Belize" & "Benin" & "Bolivia" & "Bosnia-Herzegovina" \\
\hline "Botswana" & "Brazil" & "Bulgaria" & "Burkina Faso" \\
\hline "Burundi" & "Côte d'Ivoire" & "Cambodia" & "Cameroon" \\
\hline "Central African Republic" & "Chad" & "Chile" & "Colombia" \\
\hline "Dem. Rep. Congo" & "Republic of Congo, " & "Costa Rica" & "Croatia" \\
\hline "Cuba" & "Cyprus" & "Djibouti" & "Dominica" \\
\hline "Dominican Rep." & "Ecuador" & "Egypt" & "El Salvador" \\
\hline "Eritrea" & "Ethiopia" & "Gabon" & "Gambia" \\
\hline "Georgia" & "Ghana" & "Greece" & "Guatemala" \\
\hline "Guinea" & "Guinea-Bissau" & "Guyana" & "Haiti" \\
\hline "Honduras" & "India" & "Indonesia" & "Iran" \\
\hline "Iraq" & "Israel" & "Jamaica" & "Jordan" \\
\hline "Kazakhstan" & "Kenya" & "Kosovo" & "Kuwait" \\
\hline "Kyrgyzstan" & "Laos" & "Lebanon" & "Lesotho" \\
\hline "Liberia" & "Libya" & "Madagascar" & "Malawi" \\
\hline "Malaysia" & "Mali" & "Mauritania" & "Mexico" \\
\hline "Moldova" & "Montenegro" & "Morocco" & "Mozambique" \\
\hline "Myanmar" & "Namibia" & "Nepal" & "Nicaragua" \\
\hline "Niger" & "Nigeria" & "North Macedonia" & "Pakistan" \\
\hline "Panama" & "Paraguay" & "Peru" & "Philippines" \\
\hline "Romania" & "Russia" & "Rwanda" & "Saudi Arabia" \\
\hline "Senegal" & "Sierra Leone" & "Somalia" & "South Africa" \\
\hline "South Sudan" & "Sri Lanka" & "St. Kitts and Nevis" & "St. Lucia" \\
\hline "St. Vincent and Grenadines" & "Sudan" & "Suriname" & "Swaziland" \\
\hline "Syria" & "Tajikistan" & "Tanzania" & "Thailand" \\
\hline "Togo" & "Trinidad \& Tobago" & "Tunisia" & "Turkey" \\
\hline "Turkmenistan" & "Uganda" & "Ukraine" & "Uruguay" \\
\hline "Uzbekistan" & "Venezuela" & "Viet Nam" & "Yemen" \\
\hline "Yugoslavia" & "Zambia" & "Zimbabwe" & \\
\hline
\end{tabular}




\section{Histograms and maps}
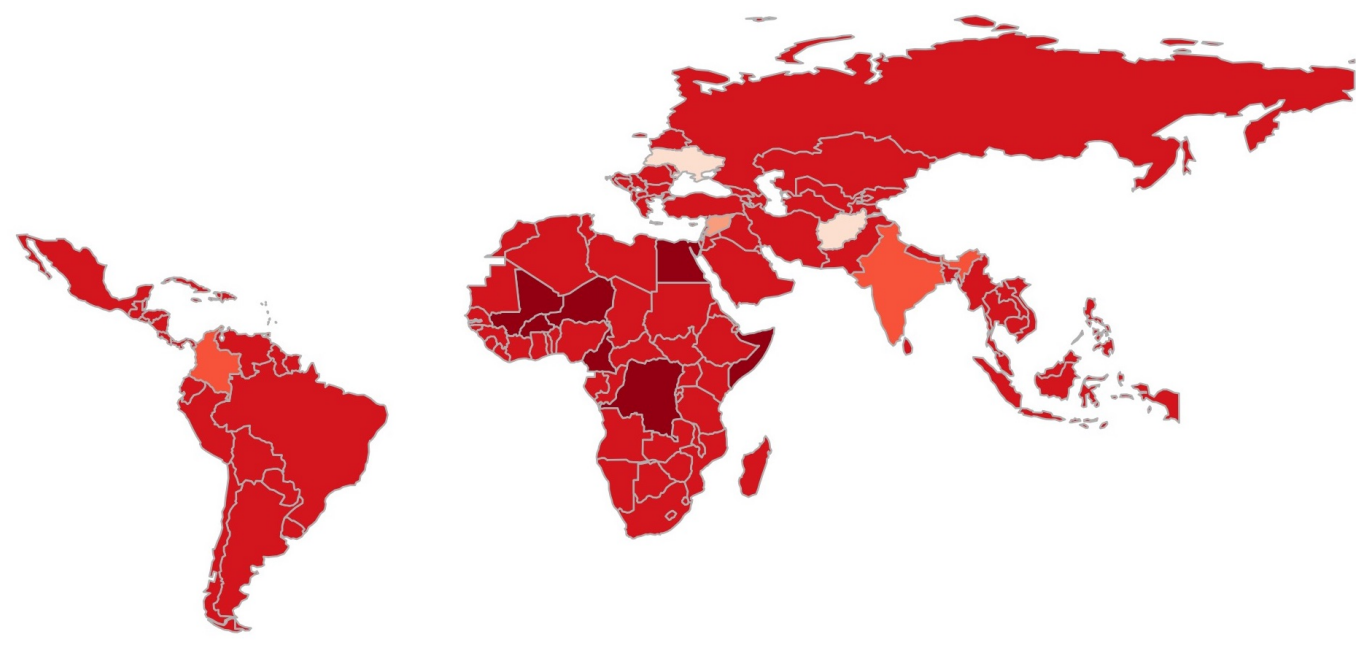

\begin{tabular}{|c|c|c|}
\hline \multicolumn{3}{|c|}{ Average Change in Number of Rebel Attacks (2019 to 2020) } \\
\hline-7 & -5 & bove zero \\
\hline
\end{tabular}

Figure A1: A map of changes in rebel attacks, 2019-2020, for all countries in the dataset
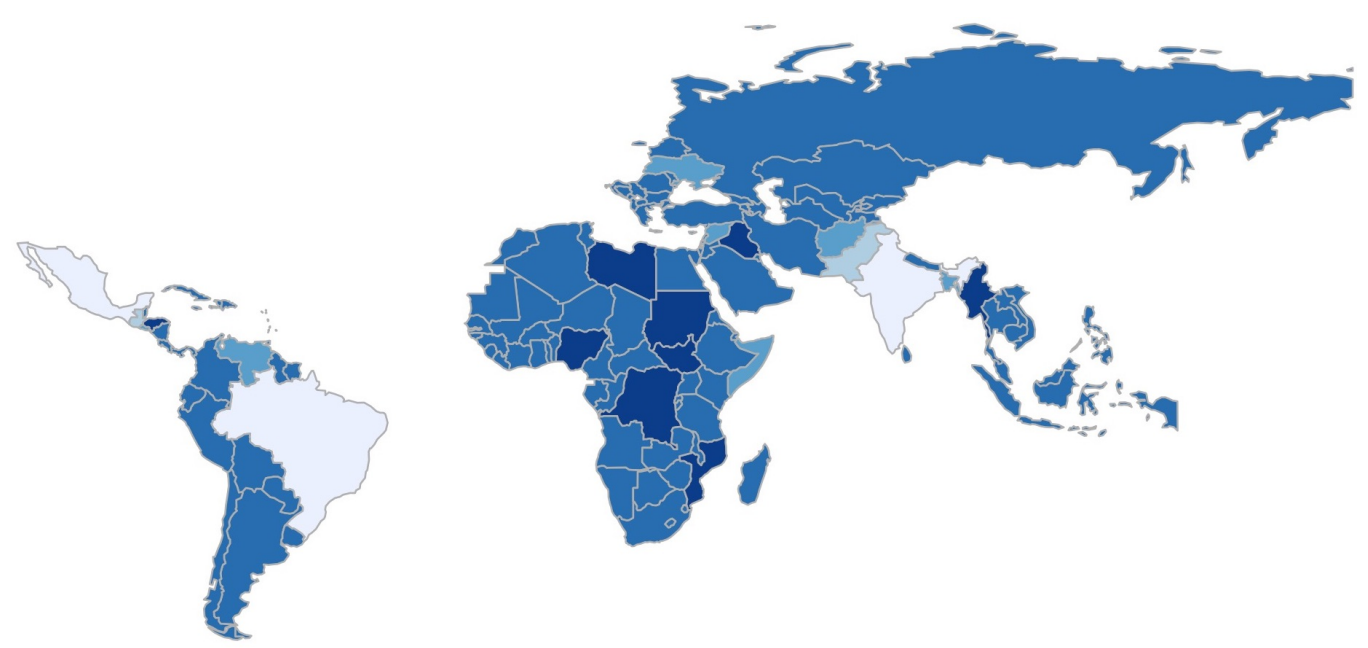

\begin{tabular}{|l|l|l|l|l|l|}
\hline \multicolumn{5}{|c|}{ Average Change in Number of PGN Attacks (2019 to 2020) } \\
\hline-5 & -3 & -1 & $\sim 0$ & +1 or more \\
\hline
\end{tabular}

Figure A2: A map of changes in PGN attacks, 2019-2020, for all countries in the dataset 

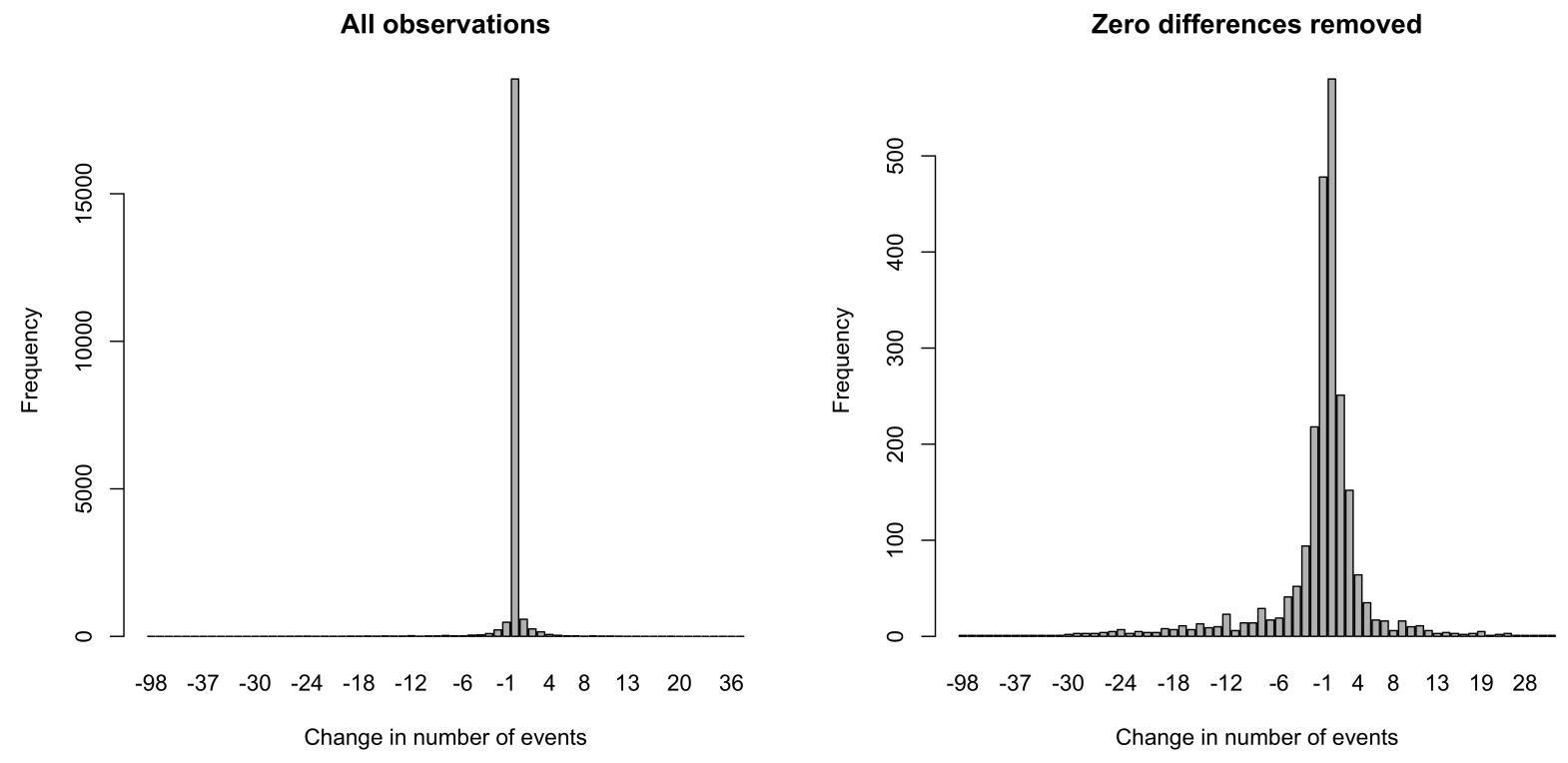

Figure A3: Histogram of change in rebel attacks, 2019 to 2020
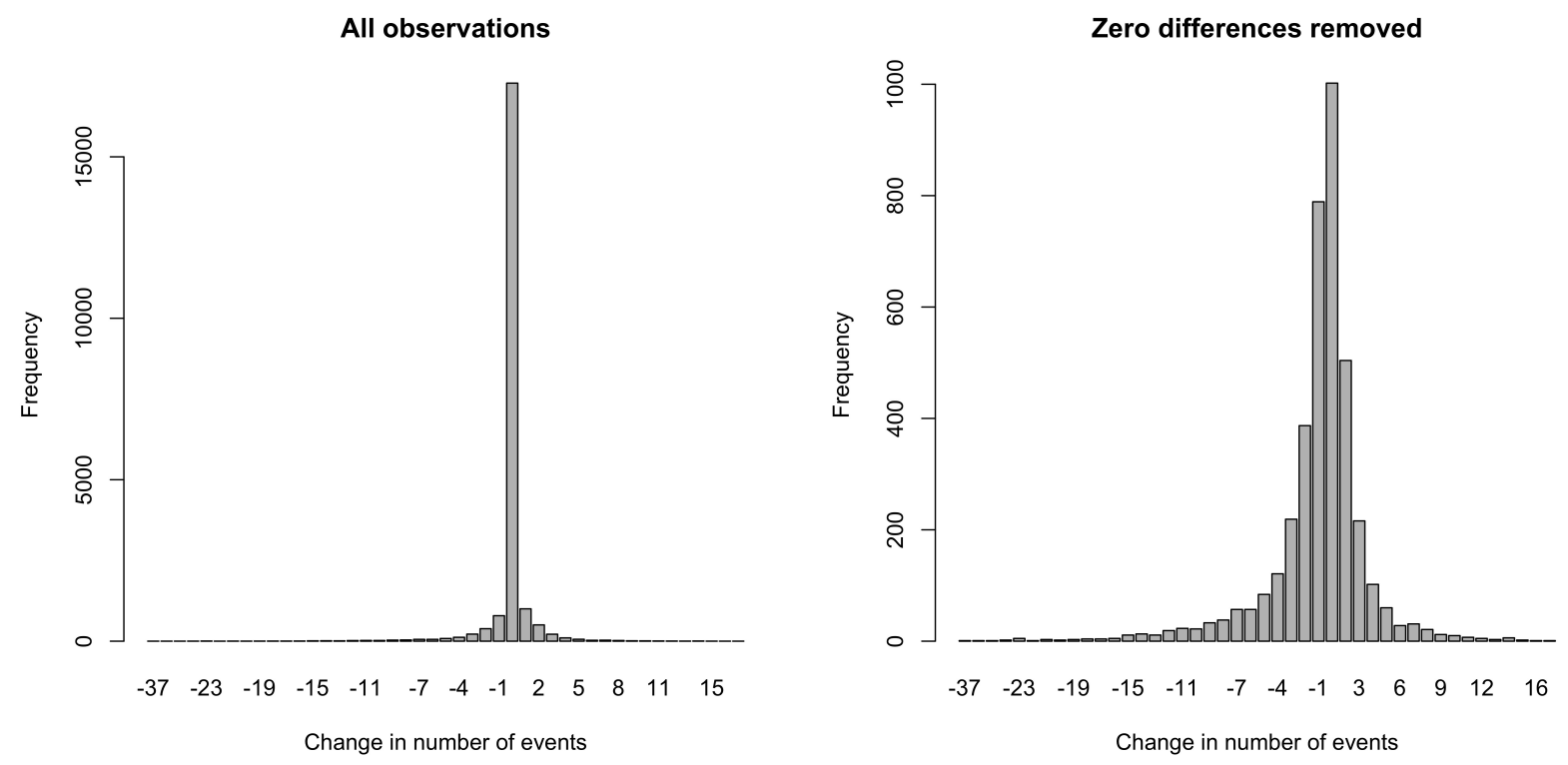

Figure A4: Histogram of change in PGN attacks, 2019 to 2020 


\section{Sensitivity Analyses}

In this section we report a large number of sensitivity analysis designed to illustrate our findings' robustness to a variety of empirical and theoretical concerns. First, we account for the possibility that our results are due to the inclusion of month fixed effects and the time trend, which - considering that we already difference our dependent variable temporally might cause us to 'over-season' our conflict data. To this end, Table A3 first reports a set of models corresponding to each respective dependent variable (and its lag) where month fixed effects were removed. This is followed by a similar set of models that additionally omits the time trend. As Table A3 illustrates, our results are not affected by these addition of these temporal controls.

Next, note that conflict by nonstate actors may exhibit both serial correlations over time and endogeneity with covid-19, considering that most unplanned disasters are the result of socioeconomic and political failures of preparedness (e.g., Jokman \& Kelman, 2005). To address this relevant concern, we employ a series of robust system generalized method of moments (GMM) dynamic models corresponding to each dependent variable. By firstdifferencing lagged values of the instrumented - i.e., the dependent - variable, such GMM models create necessary instruments 'internally.' Specifically, these models are specified as a system of (per period) equations, where the instruments applicable to each equation differ because additional lagged values of the instruments exist in later time periods (for details, see, e.g., Arellano \& Bond, 1991). Building on past econometric research and to avoid the risk of over-specification (e.g., Roodman, 2009), for these instruments, we include three-to17 day lags of each respective DV, capturing variations in these variables at time $t$ based on changes from past periods (for this reason, the time trend and month fixed effects are

omitted from these models, as their inclusions means the models fail to converse). With first-differencing exploiting over-time variations in each DV to, in effect, 'exogenize' the dependent variable, unit fixed effects are flushed out, leaving an effective, unit-of-analysis specific sets of information. 
The results from these GMM models are reported in Table A4. As the estimates show, the results of the main analysis hold. In fact, these models suggest that - once endogeneity is taken into account - covid-19 deaths have had a positive influence on rebel attacks in addition to PGN attacks, again compared with 2019 levels. Additionally, Sargan test results are statistically insignificant across both models, suggesting neither model is over-specified, thus providing additional confirmation of these results.

Next, recall that our main models relied on country fixed effects. One potential concern is that in doing so, we failed to account for potential important confounders that might explain the results. Here, we must emphasize that because our data in effect analyzed only 2020, and the fact that most countries are measured at the annual level, including relevant controls was infeasible, as relevant 2020 socioeconomic and political data are still unavailable, making them a 'fixed-effect' in practice as they do not vary by the day (and in any case, these data are likely autocorrelated to some extent with the spread of covid-19). Moreover, especially in conflict-afflicted states, such data from main datasets, such as the World Bank's World Development Indicators (WDI), suffer from very high level of missingness, which would result with a large number of cases being omitted from analysis not-at-random (that is, because they experience conflict). Research also shows that such 'controls' likely bias estimates, and do not have a straightforward interpretation, in causal models (Keele et al., 2020).

Nevertheless, to illustrate that our findings are reasonably robust to this concern, we collected a large number of confounders from datasets for the latest period for which these data were available (again, not accounting for missingness due to issues such as ongoing conflicts). To this end, Table A5 first reports the same models from Table 1 in the main paper, with the addition of the following controls: (i) (logged) nighttime emission by country (from the PRIO-Grid dataset, aggregated to the country level, latest year available in these data is 2014; see Tollefsen et al. 2012); (ii) (logged) population and (iii) real GDP per capita levels (both obtained from Gleditsch, 2002 and expanded to 2011, the last year available 
in the data, which is used here) ${ }^{1}$ (iv) military expenditure by country (obtained from the Stockholm International Peace Research Institute, or SIPRI; last year available in the data is 2019); (v) Polity2 data from the Polity IV data series (Marshall \& Jaggers, 2002; last year available in the data was 2018); (vi) oil rents as percent of GDP (from the WDI; last year available in the data was 2017); and finally indicators accounting for (vii) percent country area that is mountainous, (viii) ethnic and (ix) religious fractionalization (from Fearon \& Laitin, 2003). To account for other country specific issues, we replaced our country fixed effect with random effects by country, which allow one to model time-invariant covariates while still accounting for unit-specific features.

Next, there is the possibility that differences in violence are affected by the number of rebel groups and PGNs operating in a given country. To this end, the next set of models in Table A5 add indicators for the number of rebel groups and PGNs to the same specifications from Table 1, main paper, but for the random effects by country models. The last two models in Table A5 then add to these indicators the same controls used in the first two models in the same tables (and discussed above). Crucially, the results of these random effect control-inclusive models in Table A4 clearly show that adding these indicators does not impact the sign, statistical significance, and magnitude of the effects observed in Table 1 in the main text.

The next set of tests, in Table A6, account for longer dependencies of violence over time, adding deeper DV lags to the data. When then illustrate that the results are also robust to our decision to lag and log our key explanatory variable.

Another potential concern is our decision to rely on the country-day as our unit of analysis. This decision could constitute an over-disaggregation of our data, although we believe the the large number of events at this level suggests this is not the case. Nevertheless, to ensure that our results the first set of models in Table A7 re-estimate Table 1 from the main paper where data where aggregated to the weekly level, and where the unit of

\footnotetext{
${ }^{1}$ We prefer these data to the WDI because they suffer from far less missingness across countries and years.
} 
analysis is - accordingly - the country-weeks (accordingly, the time trend is in this model is changed to a weekly indicator of all weeks in 2020 in our data). We then illustrated that our results are robust to endogeneity concerns and serial correlation even at this higher level of disaggregation by running GMM models corresponding to those reported in Table A4, only this time where temporal variations are exploited at the country-week level. The robustness of the results at these higher level of temporal disaggregation lead additional confirmation that by deciding to rely on the country-day to exploit the maximal level of variability in the data, we are not biasing our results in terms of sign or statistical significance.

In Table A8 we turn to evaluate whether our results are sensitive to different facets of our sample, which can induce possible bias (although more likely than not toward rather than away from zero). One potential concern is that the results are driven by the weakest states in our sample, where PGN and rebel activity are both more likely (Fearon \& Laitin, 2003). To this end, the first set of models in Table A8 re-estimate Table 1 from the main paper using only countries with relatively high state capacity, that is countries whose nighttime emission levels (in 2014) where above the global median. Another possibility is that, as Figures A3-A4 above illustrate, most of the country-days in our sample experienced zero violence events both in 2019 and 2020. Accordingly, in the next two models we remove all countries where no attacks by rebels and PGNs, respectively, were reported in 2020, to focus only on states that experienced violence in 2020. Finally, recall that violence trends at the daily level might experience cycles related to holidays and periods where people enjoy more free times. Accordingly, the last two models in Table A8 add an indicator accounting for whether a given day was a weekend day (Sundays and Saturdays) or not.

Next, although one of the reason we choose to rely on deaths from covid-19 rather than cases (in addition to the massive variations in the latter across states) is because doing so incorporates some of the time it might take the disease to impact conflict patterns, there is a possibility that some of the effects of covid-19 on nonstate activity might unfold over periods longer than the one-day lag we included in the model. To this end, Table A9 reports 
three sets of models, where the main explanatory variables, (logged) covid-19 deaths (per million), was lagged by (i) two, (ii) seven, and (iii) ten day period to account for such lags. Again, the sign, statistical significance, and magnitude on the coefficients of our variables of interest hold across these three sets of models, illustrating our conclusions are robust to these lagging concerns as well.

Finally, as we mentioned above when discussing the models in Table A7, the daily attack data may be too fine-grained as to introduce potential infernetial problems (e.g., with respect to religious holidays).Accordingly, in Table A10, we report a set of models where the dependent variables are operationalized as the daily attacks figures subtracted from the monthly averages in each month in 2020. This indicator, which is linked to monthly averages may capture some trends and patterns better, although zero inflation in our data is more likely to bias estimates toward zero rather than the other way around. Indeed, the estimates reported in Table A10 suggest that when this more aggregated dependent variable is used, the coefficient estimates for Covid-19 deaths $s_{i t-1}$ are positive and statistically significant not only with respect to changes in PGN attacks, but also with respect to rebel attacks. Overall, then, Tables A3-A10 subject our main findings to a host of analysis and show that the sign, statistical significance, and magnitude on the coefficients of our variables of interest hold in every case. Indeed, in some cases (Tables A4 and A10), we find that the results confirm a positive relationship between covid-19 deaths and rebel violence. These robustness analyses hence suggest that our conclusions from the main paper cannot be immediately dismissed as random. 
Table A3: Determinants of Nonstate Actor Attacks - Temporal Sensitivity

\begin{tabular}{|c|c|c|c|c|}
\hline & \multicolumn{2}{|c|}{ No Month FEs } & \multicolumn{2}{|c|}{ No Month FEs + No Time Trend } \\
\hline & $\Delta$ rebel attacks ${ }_{i t}$ & $\Delta P G N$ attacks $_{i t}$ & $\Delta$ rebel attacks $_{i t}$ & $\triangle P G N$ attacks $_{i t}$ \\
\hline Covid-19 deaths $_{i t-1}{ }^{1}$ & $\begin{array}{c}0.010 \\
(0.019)\end{array}$ & $\begin{array}{c}0.048^{* * *} \\
(0.016)\end{array}$ & $\begin{array}{c}-0.0003 \\
(0.014)\end{array}$ & $\begin{array}{c}0.028^{* *} \\
(0.012)\end{array}$ \\
\hline$D V_{i t-1}$ & $\begin{array}{c}0.450^{* * *} \\
(0.006)\end{array}$ & $\begin{array}{c}0.189^{* * *} \\
(0.007)\end{array}$ & $\begin{array}{c}0.450^{* * *} \\
(0.006)\end{array}$ & $\begin{array}{c}0.189^{* * *} \\
(0.007)\end{array}$ \\
\hline$\tau_{t}$ & $\begin{array}{l}-0.0003 \\
(0.0004)\end{array}$ & $\begin{array}{l}-0.001^{*} \\
(0.0003)\end{array}$ & - & - \\
\hline Constant & $\begin{array}{c}0.017 \\
(0.148)\end{array}$ & $\begin{array}{c}0.015 \\
(0.125)\end{array}$ & $\begin{array}{c}0.0002 \\
(0.147)\end{array}$ & $\begin{array}{l}-0.017 \\
(0.124)\end{array}$ \\
\hline Observations & & 209 & & 209 \\
\hline & 0.313 & 0.187 & 0.313 & 0.187 \\
\hline Adjusted $\mathrm{R}^{2}$ & 0.309 & 0.182 & 0.309 & 0.182 \\
\hline
\end{tabular}

${ }^{*} \mathrm{p}<0.1 ;{ }^{* *} \mathrm{p}<0.05 ;{ }^{* * *} \mathrm{p}<0.01$. Variable coefficients are reported with standard errors clustered by country in parentheses. Fixed effects by country are included in each model although none is reported here.

${ }^{1}$ Natural $\log$ 
Table A4: Determinants of Nonstate Actor Attacks - Serial Correlation and Endogeneity

\begin{tabular}{|c|c|c|}
\hline & \multicolumn{2}{|c|}{ GMMs } \\
\hline & $\Delta$ rebel attacks $s_{i t}$ & $\triangle P G N$ attacks $_{i t}$ \\
\hline Covid-19 deaths $s_{i t-1}{ }^{1}$ & $\begin{array}{c}0.510^{* * * *} \\
(0.163)\end{array}$ & $\begin{array}{c}0.943^{* * *} \\
(0.297)\end{array}$ \\
\hline$D V_{i t-1}$ & $\begin{array}{c}0.431^{* * *} \\
(0.025)\end{array}$ & $\begin{array}{c}0.119^{* * *} \\
(0.035)\end{array}$ \\
\hline Observations & \multicolumn{2}{|c|}{21,209} \\
\hline Sargan test & 48.505 & 89.604 \\
\hline
\end{tabular}

${ }^{*} \mathrm{p}<0.1 ;{ }^{* *} \mathrm{p}<0.05 ;{ }^{* * *} \mathrm{p}<0.01$. Variable coefficients are reported with standard errors clustered by country in parentheses for the control models. Fixed effects by country and month are included in both control models although none is reported here.

${ }^{1}$ Natural $\log$ 
Table A5: Determinants of Nonstate Actor Attacks - RE with Confounders

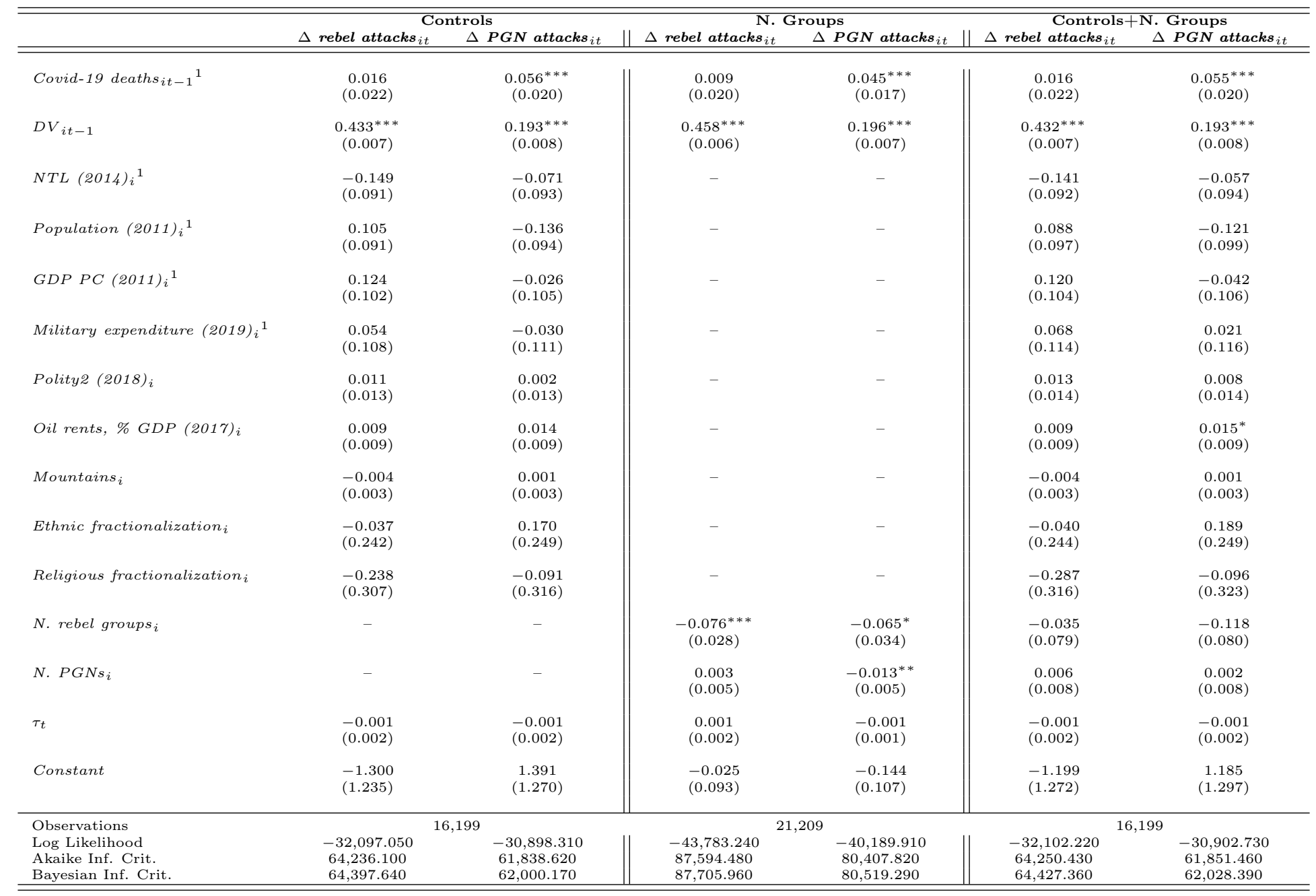

${ }^{*} \mathrm{p}<0.1 ;{ }^{* *} \mathrm{p}<0.05 ;{ }^{* * *} \mathrm{p}<0.01$. Variable coefficients are reported with standard errors clustered by country in parentheses for the control models. Fixed effects by country and month are included in both control models although none is reported here.

${ }^{1}$ Natural log 
Table A6: Determinants of Nonstate Actor Attacks - Main Variable operationalization

\begin{tabular}{|c|c|c|c|c|c|c|}
\hline & \multicolumn{2}{|c|}{ Deeper DV Lags } & \multicolumn{2}{|c|}{ Nonlagged EV } & \multicolumn{2}{|c|}{ Nonlogged EV } \\
\hline & $\Delta$ rebel attacks ${ }_{i t}$ & $\Delta P_{P N}$ attacks $_{i t}$ & $\| \Delta$ rebel attacks $_{i t}$ & $\Delta P G N$ attacks $_{i t}$ & $\Delta$ rebel attacks $_{i t}$ & $\Delta$ PGN attacks $_{i t}$ \\
\hline Covid-19 deaths $s_{i t-1}{ }^{1}$ & $\begin{array}{c}0.012 \\
(0.021)\end{array}$ & $\begin{array}{c}0.044^{* *} \\
(0.017)\end{array}$ & $\begin{array}{c}0.012 \\
(0.021)\end{array}$ & $\begin{array}{c}0.053^{* * *} \\
(0.018)\end{array}$ & $\begin{array}{l}3.934 \mathrm{e}-06 \\
(0.001)\end{array}$ & $\begin{array}{c}0.002^{* *} \\
(0.001)\end{array}$ \\
\hline$D V_{i t-1}$ & $\begin{array}{c}0.380^{* * *} \\
(0.007)\end{array}$ & $\begin{array}{c}0.160^{* * *} \\
(0.007)\end{array}$ & $\begin{array}{c}0.450^{* * *} \\
(0.006)\end{array}$ & $\begin{array}{c}0.189^{* * *} \\
(0.007)\end{array}$ & $\begin{array}{c}0.450^{* * *} \\
(0.006)\end{array}$ & $\begin{array}{c}0.189^{* * *} \\
(0.007)\end{array}$ \\
\hline$D V_{i t-2}$ & $\begin{array}{c}0.048^{* * *} \\
(0.007)\end{array}$ & $\begin{array}{c}0.123^{* * *} \\
(0.007)\end{array}$ & - & - & - & - \\
\hline$D V_{i t-3}$ & $\begin{array}{c}0.158^{* * *} \\
(0.007)\end{array}$ & $\begin{array}{c}0.016^{* *} \\
(0.007)\end{array}$ & & & & \\
\hline$\tau_{t}$ & $\begin{array}{c}0.001 \\
(0.002)\end{array}$ & $\begin{array}{l}-0.001 \\
(0.001)\end{array}$ & $\begin{array}{c}0.001 \\
(0.002)\end{array}$ & $\begin{array}{l}-0.001 \\
(0.001)\end{array}$ & $\begin{array}{c}0.001 \\
(0.002)\end{array}$ & $\begin{array}{l}-0.001 \\
(0.001)\end{array}$ \\
\hline Constant & $\begin{array}{l}-0.016 \\
(0.149)\end{array}$ & $\begin{array}{c}0.017 \\
(0.127)\end{array}$ & $\begin{array}{l}-0.022 \\
(0.151)\end{array}$ & $\begin{array}{c}0.006 \\
(0.127)\end{array}$ & $\begin{array}{l}-0.022 \\
(0.151)\end{array}$ & $\begin{array}{c}0.013 \\
(0.127)\end{array}$ \\
\hline Observations & & 955 & & 209 & & 209 \\
\hline & 0.342 & 0.200 & 0.313 & 0.187 & 0.313 & 0.187 \\
\hline Adjusted $\mathrm{R}^{2}$ & 0.338 & 0.195 & 0.309 & 0.182 & 0.309 & 0.182 \\
\hline
\end{tabular}

${ }^{*} \mathrm{p}<0.1 ;{ }^{* *} \mathrm{p}<0.05 ;{ }^{* * *} \mathrm{p}<0.01$. Variable coefficients are reported with standard errors clustered by country in parentheses. Fixed effects by country and month are included in each model although none is reported here.

${ }^{1}$ Natural log (excluding the nonlogged models) 
Table A7: Determinants of Nonstate Actor Attacks - Week-Level Models

\begin{tabular}{|c|c|c|c|c|}
\hline & \multicolumn{2}{|c|}{$\overline{\mathrm{OLS}}$} & \multicolumn{2}{|c|}{ GMM } \\
\hline & $\Delta$ rebel $^{\text {attacks }_{i t}}$ & $\Delta P G N$ attacks $_{i t}$ & $\Delta$ rebel $^{\text {attacks }_{i t}}$ & $\Delta P G N$ attacks $_{i t}$ \\
\hline Covid-19 deaths $_{i t-1}{ }^{1}$ & $\begin{array}{c}0.187 \\
(0.150)\end{array}$ & $\begin{array}{l}0.202^{*} \\
(0.106)\end{array}$ & $\begin{array}{c}0.504 \\
(0.640)\end{array}$ & $\begin{array}{c}1.102^{* * *} \\
(0.417)\end{array}$ \\
\hline$D V_{i t-1}$ & $\begin{array}{c}0.393^{* * *} \\
(0.016)\end{array}$ & $\begin{array}{c}0.283^{* * *} \\
(0.018)\end{array}$ & $\begin{array}{c}0.342^{* * *} \\
(0.090)\end{array}$ & $\begin{array}{c}0.240^{* * *} \\
(0.092)\end{array}$ \\
\hline Week ind.t & $\begin{array}{c}0.089 \\
(0.161)\end{array}$ & $\begin{array}{l}-0.099 \\
(0.114)\end{array}$ & & \\
\hline Constant & $\begin{array}{l}-0.050 \\
(1.613)\end{array}$ & $\begin{array}{l}-0.108 \\
(1.142)\end{array}$ & & \\
\hline Observations & & 921 & & \\
\hline & 0.452 & 0.468 & & \\
\hline Adjusted $\mathrm{R}^{2}$ & 0.425 & 0.441 & & \\
\hline Sargan test & & & 85.140 & 100.365 \\
\hline
\end{tabular}

${ }^{*} \mathrm{p}<0.1 ;{ }^{* *} \mathrm{p}<0.05 ;{ }^{* * *} \mathrm{p}<0.01$. Variable coefficients are reported with standard errors in parentheses and country-clustered SEs in the OLS models. Fixed effects by country and month are included in the OLS models although none is reported here.

1 Natural $\log$ 
Table A8: Determinants of Nonstate Actor Attacks - State Capacity, Zero Inflation, Weekends

\begin{tabular}{|c|c|c|c|c|c|c|}
\hline & \multicolumn{2}{|c|}{ High SC } & \multicolumn{2}{|c|}{ No Zeros } & \multicolumn{2}{|c|}{ Weekends } \\
\hline & $\Delta$ rebel attacks $_{i t}$ & $\triangle P G N$ attacks $_{i t}$ & $\Delta$ rebel $_{\text {attacks }_{i t}}$ & $\Delta P G N$ attacks $_{i t}$ & $\Delta$ rebel attacks $_{i t}$ & $\triangle P G N$ attacks $_{i t}$ \\
\hline Covid-19 deaths ${ }_{i t-1}{ }^{1}$ & $\begin{array}{c}0.032 \\
(0.040)\end{array}$ & $\begin{array}{c}0.098^{* * *} \\
(0.033)\end{array}$ & $\begin{array}{c}0.046 \\
(0.085)\end{array}$ & $\begin{array}{c}0.077^{* * *} \\
(0.024)\end{array}$ & $\begin{array}{c}0.012 \\
(0.021)\end{array}$ & $\begin{array}{c}0.054^{* * *} \\
(0.018)\end{array}$ \\
\hline$D V_{i t-1}$ & $\begin{array}{c}0.466^{* * *} \\
(0.009)\end{array}$ & $\begin{array}{c}0.191^{* * *} \\
(0.010)\end{array}$ & $\begin{array}{c}0.448^{* * *} \\
(0.012)\end{array}$ & $\begin{array}{c}0.188^{* * *} \\
(0.008)\end{array}$ & $\begin{array}{c}0.450^{* * *} \\
(0.006)\end{array}$ & $\begin{array}{c}0.189^{* * *} \\
(0.007)\end{array}$ \\
\hline Weekend $_{i t}$ & - & - & - & - & $\begin{array}{c}0.005 \\
(0.029)\end{array}$ & $\begin{array}{l}-0.024 \\
(0.024)\end{array}$ \\
\hline$\tau_{t}$ & $\begin{array}{c}0.002 \\
(0.003)\end{array}$ & $\begin{array}{l}-0.002 \\
(0.002)\end{array}$ & $\begin{array}{c}0.003 \\
(0.006)\end{array}$ & $\begin{array}{l}-0.002 \\
(0.002)\end{array}$ & $\begin{array}{c}0.001 \\
(0.002)\end{array}$ & $\begin{array}{l}-0.001 \\
(0.001)\end{array}$ \\
\hline Constant -0.049 & $\begin{array}{c}0.053 \\
(0.215)\end{array}$ & $\begin{array}{l}-0.237 \\
(0.174)\end{array}$ & $\begin{array}{c}0.006 \\
(0.311)\end{array}$ & $\begin{array}{l}-0.023 \\
(0.148)\end{array}$ & $\begin{array}{c}0.012 \\
(0.151)\end{array}$ & $(0.127)$ \\
\hline Observations & 10,521 & 10,521 & 5,845 & 16,032 & 21,209 & 21,209 \\
\hline & 0.326 & 0.194 & 0.311 & 0.187 & 0.313 & 0.187 \\
\hline Adjusted $\mathrm{R}^{2}$ & 0.321 & 0.189 & 0.306 & 0.181 & 0.309 & 0.182 \\
\hline
\end{tabular}

${ }^{*} \mathrm{p}<0.1 ;{ }^{* *} \mathrm{p}<0.05 ;{ }^{* * *} \mathrm{p}<0.01$. Variable coefficients are reported with standard errors clustered by country in parentheses. Fixed effects by country and month are included in each model although none is reported here.

${ }^{1}$ Natural $\log$ 
Table A9: Determinants of Nonstate Actor Attacks - Deeper EV Lags

\begin{tabular}{|c|c|c|c|c|c|c|}
\hline & \multicolumn{2}{|c|}{ Two Days } & \multicolumn{2}{|c|}{ Seven Days } & \multicolumn{2}{|c|}{ Ten Days } \\
\hline & $\Delta$ rebel attacks $_{i t}$ & $\Delta P G N$ attacks $_{i t}$ & $\| \Delta$ rebel attacks $_{i t}$ & $\Delta P G N$ attacks $_{i t}$ & $\| \Delta$ rebel attacks ${ }_{i t}$ & $\triangle P G N$ attacks $_{i t}$ \\
\hline Covid-19 deaths $_{i t-2}{ }^{1}$ & $\begin{array}{c}0.013 \\
(0.021)\end{array}$ & $\begin{array}{c}0.052^{* * *} \\
(0.018)\end{array}$ & - & - & - & - \\
\hline Covid-19 deaths $_{i t-7^{1}}$ & - & - & $\begin{array}{c}0.023 \\
(0.021)\end{array}$ & $\begin{array}{c}0.039^{* *} \\
(0.018)\end{array}$ & - & - \\
\hline Covid-19 deaths ${ }_{i t-10^{1}}$ & - & - & - & - & $\begin{array}{l}0.035^{*} \\
(0.021)\end{array}$ & $\begin{array}{l}0.037^{*} \\
(0.019)\end{array}$ \\
\hline$D V_{i t-1}$ & $\begin{array}{c}0.452^{* * *} \\
(0.006)\end{array}$ & $\begin{array}{c}0.188^{* * *} \\
(0.007)\end{array}$ & $\begin{array}{c}0.423^{* * *} \\
(0.006)\end{array}$ & $\begin{array}{c}0.190^{* * *} \\
(0.007)\end{array}$ & $\begin{array}{c}0.381^{* * *} \\
(0.006)\end{array}$ & $\begin{array}{c}0.194^{* * *} \\
(0.007)\end{array}$ \\
\hline$\tau_{t}$ & $\begin{array}{c}0.001 \\
(0.002)\end{array}$ & $\begin{array}{l}-0.001 \\
(0.001)\end{array}$ & $\begin{array}{l}-0.0005 \\
(0.002)\end{array}$ & $\begin{array}{l}-0.001 \\
(0.001)\end{array}$ & $\begin{array}{l}-0.001 \\
(0.002)\end{array}$ & $\begin{array}{l}-0.001 \\
(0.001)\end{array}$ \\
\hline Constant & $\begin{array}{l}-0.018 \\
(0.152)\end{array}$ & $\begin{array}{c}0.002 \\
(0.128)\end{array}$ & $\begin{array}{c}0.023 \\
(0.152)\end{array}$ & $\begin{array}{l}-0.006 \\
(0.130)\end{array}$ & $\begin{array}{c}0.073 \\
(0.146)\end{array}$ & $\begin{array}{l}-0.018 \\
(0.132)\end{array}$ \\
\hline Observations & \multicolumn{2}{|c|}{21,082} & \multicolumn{2}{|c|}{20,447} & \multicolumn{2}{|c|}{20,066} \\
\hline $\mathrm{R}^{2}$ & 0.316 & 0.188 & 0.299 & 0.188 & 0.303 & 0.188 \\
\hline Adjusted $\mathrm{R}^{2}$ & 0.311 & 0.183 & 0.295 & 0.182 & 0.298 & 0.183 \\
\hline
\end{tabular}

${ }^{*} \mathrm{p}<0.1 ;{ }^{* *} \mathrm{p}<0.05 ;{ }^{* * *} \mathrm{p}<0.01$. Variable coefficients are reported with standard errors clustered by country in parentheses. Fixed effects by country and month are included in each model although none is reported here.

${ }^{1}$ Natural $\log$ 
Table A10: Determinants of Nonstate Actor Attacks - Monthly Level Averages

\begin{tabular}{|c|c|c|}
\hline & $\Delta$ rebel $^{\text {attacks }_{i t}}$ & $\Delta P G N$ attacks $_{i t}$ \\
\hline Covid-19 deaths $s_{i t-1}{ }^{1}$ & $\begin{array}{c}0.038^{* * *} \\
(0.006)\end{array}$ & $\begin{array}{c}0.051^{* * *} \\
(0.004)\end{array}$ \\
\hline$D V_{i t-1}$ & $\begin{array}{c}0.625^{* * *} \\
(0.004)\end{array}$ & $\begin{array}{c}0.738^{* * *} \\
(0.003)\end{array}$ \\
\hline Constant & $\begin{array}{l}-0.036 \\
(0.067)\end{array}$ & $\begin{array}{l}-0.051 \\
(0.043)\end{array}$ \\
\hline Observations & \multicolumn{2}{|c|}{17,272} \\
\hline & 0.625 & 0.737 \\
\hline Adjusted $\mathrm{R}^{2}$ & 0.622 & 0.735 \\
\hline
\end{tabular}

${ }^{*} \mathrm{p}<0.1 ;{ }^{* *} \mathrm{p}<0.05 ;{ }^{* * *} \mathrm{p}<0.01$. Variable coefficients are reported with standard errors clustered by country in parentheses for the control models. Fixed effects by country and month are included in both control models although none is reported here.

${ }^{1}$ Natural log 


\section{Case Studies: Additional Information}

\section{Case selection discussion}

Afghanistan and Nigeria present an interesting comparison because while they do exhibit differences, there are also key similarities between them. Although Afghanistan (a Muslim majority country) is less religiously diverse than Nigeria (with a Muslim-majority North and Christian-majority South), both countries are ethnically and linguistically diverse and have faced similar ethnolinguistic challenges in forming a unified national identity, in addition to addressing issues of diverse ethnolinguistic representation in their parliaments (CIA, 2021a;2021b; Dupree, 2021; Folami, 2017; Hamilton Millard Kirk-Greene, 2021; Ikpe, 2009; Sinno, 2015). In both Afghanistan and Nigeria, failures to create an effective ethnic coalition have induced the government to resort to violence at various points in order to maintain control over these varied groups.

While some may consider Nigeria more democratic than Afghanistan today, this is a recent development, as the country's most recent constitution has been written in 1999 after decades of dictatorship and military rule since independence in 1960 (Hamilton Millard KirkGreene, 2021; Ikpe, 2009; CIA, 2021b). Afghanistan, which has been ruled by a king for most of the 20th century, prior to spells of democratic, communist and Islamic regimes, has signed its newest democratic constitution into law in 2004 (CIA, 2021a; Dupree, 2021; George \& Tassal, 2020). Although both Afghanistan and Nigeria are currently presidential democracies with rotating leaders who are electorally elected, both states have had to deal with local and regional power structures that have been incompatible with their central governments. And although Nigeria has a stronger military force than Afghanistan, both states have been enmeshed in decades-long conflict with a primary opposition group - the Taliban in Afghanistan, since it was removed from power in 2001, and Boko Haram in Nigeria since 2002 - in addition to other, less significant opposition and insurgent groups (CIA 2021a; 2021b; Dorff et al., 2020; Dupree, 2021; George \& Tassal, 2020; Hamilton Millard Kirk-Greene, 2021). 
In addition to facing multiple anti-state actors, each country's government also have similar dealings with pro-government nonstate actors (PGNs), especially in locations and during times when the state was facing challenging in keeping opposition groups at check (CIA, 2021a; 2021b; Ahram, 2011; Ambrozik, 2019; Carey \& Mitchell, 2017; Raleigh \& Kishi, 2020). Finally, both states are also heavily primary commodity dependent, and both rely on their oil reserves as a primary source of economic prosperity. As a result, both governments have experienced different stints and cases of major corruption, both related and unrelated to these reserves (Dupree, 2021; Hamilton Millard Kirk-Greene, 2021). 


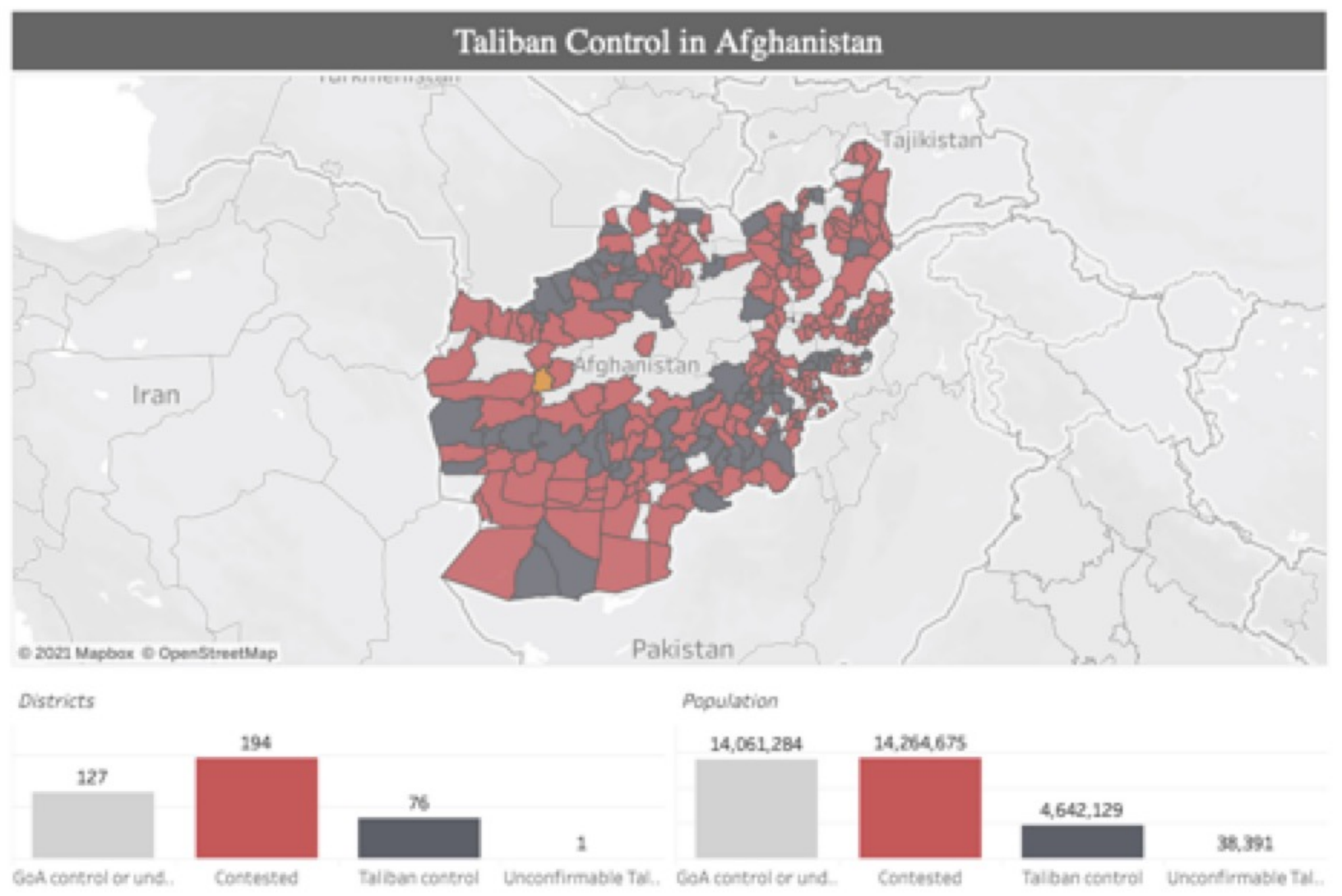

Figure A5: Source: Roggio \& Gutowski, 2021

Roggio \& Gutowski (2021) have been tracking Taliban control for nearly two decades using their own data gathering technique and the reports of the US government (see Figure A5). Sometimes these assessments align, but for many of the regions, such as Qala Ka, Farah, Roggio and Gutowski's assessment of who has control differs from that of the US government. There are strictly government-controlled areas (light grey), strictly Taliban controlled areas (dark grey), and contested areas (red). The map above shows Roggio and Gutowski's breakdown of these three types of regions as of early 2021, but most of these regions have been in similar circumstances since 2015. About 59 districts are under Taliban control, while 229 districts are under government control, and 119 are contested (Chughtai, 2019; George 
\& Tassal, 2020). Most of the areas the Taliban controlled in 2020, it had been in control of for the last five or more years. Many of the contested areas have also remained consistent over the last five to six years. The one major change, which happened in Farsi, Harat (in orange on the map above), was the Taliban invading in October of 2019 and the government leaving in July of 2020 after a significant amount of casualties (Roggio \& Gutowski, 2021). This was the most territory the Taliban has gained since 2016 and was a major loss for the Afghanistan government (CFR, 2021). 


\section{U.S.-Taliban 2020 agreement}

The US government has been working closely with the Islamic Republic of Afghanistan (Afghanistan) for nearly 20 years, but relationships between the US and the Islamic Emirate of Afghanistan (the Taliban) have been disjointed and tense during the same timeframe (Joint Declaration, 2020). After years of fighting, the Taliban, Afghanistan, and the US were spurred to make a peace agreement, known as the Agreement for Bringing Peace to Afghanistan in late February of 2020 (Allen, 2020).

The peace agreement primarily focused on four main components: protection of the US from Afghanistan attacks; a timeline for withdrawal of foreign forces from Afghanistan; the beginning of intra-Afghan negotiations between Afghanistan and the Taliban after the withdrawal of all foreign forces; talks for a permanent ceasefire between Afghanistan and the Taliban (Agreement for Bringing Peace to Afghanistan, 2020). This agreement only became feasible after nine rounds of talks. One key points of contention, from the point of the US and the UN, was that women's rights were not directly being addressed (Maizland, 2020). The protection of women's rights were ultimately not addressed in the agreement and because of the weakness of the Afghani government, many are skeptical of the agreement and the Taliban's ability to uphold the agreement.

Throughout most of 2020, the Taliban has not upheld most of the agreed-upon points of the ceasefire and peace agreement, at least partly because covid-19 enabled it to operate more freely in different regions (Marty, 2021). Although initially remaining peaceful and working hard to ensure covid-19 relief measures were in place, the details of the peace agreement and negotiations for moving forward did not start until September of 2020 and the rules finalized in December of 2020 (Marty, 2021). 


\section{References}

Ahram, A. I. (2011). Origins and Persistence of State-Sponsored Militias: Path Dependent Processes in Third World Military Development. Journal of Strategic Studies, 34(4), 531-556.

Allen, J. R. (2020, March 5). The US-Taliban peace deal: A road to nowhere. The Brookings Institute. https://www.brookings.edu/blog/order-from-chaos/2020/03/05/ the-us-taliban-peace-deal-a-road-to-nowhere/

Ambrozik, C. (2019). Not Whether, But When? Governments' Use of Militias in War. Security Studies, 28(5), 870-900.

Arellano, M., \& Bond, S. (1991). Some tests of specification for panel data: Monte Carlo evidence and an application to employment equations. The review of economic studies, 58(2), 277-297.

Carey, S. C., \& Mitchell, N. J. (2017). Progovernment Militias. The Annual Review of Political Science, 20, 24.

Central Intelligence Agency (CIA). 2021a. Afghanistan. In The World Factbook. CIA.

Central Intelligence Agency (CIA). 2021b. Nigeria. In The World Factbook. CIA.

Chughtai, A. (2019, June 24). Afghanistan: Who controls what. Al Jazeera. https: //www.aljazeera.com/news/2019/6/24/afghanistan-who-controls-what.

Council on Foreign Relations (CFR) (2021, April). Global Conflict Tracker. https://www . cfr.org/global-conflict-tracker/conflict/war-afghanistan.

Dorff, C., Gallop, M., \& Minhas, S. (2020). Networks of Violence: Predicting Conflict in Nigeria. The Journal of Politics, 82(2), 476-493.

Dupree, L. (2021). Afghanistan. In Encyclopedia Britannica. Britannica.

Fearon, J. D., \& Laitin, D. D. (2003). Ethnicity, insurgency, and civil war. American political 
science review, 97(1) 75-90.

Folami, O. M. (2017). Ethnic-conflict and its manifestations in the politics of recognition in a multi-ethnic Niger delta region. Cogent Social Sciences, 3(1). https://doi.org/10. $1080 / 23311886.2017 .1358526$.

Gleditsch, K.S. (2002). Expanded trade and GDP data. Journal of Conflict Resolution, 46(5), 712-724.

George, S., \& Tassal, A. (2020, December 29). How life under Taliban rule in Afghanistan has changed-And how it hasn't. The Washington Post. https://www.washingtonpost. com/graphics/2020/world/asia/afghanistan-taliban-rule-territory/.

Hamilton Millard Kirk-Greene, A. (2021). Nigeria. In Encyclopedia Britannica. Britannica. Ikpe, U. B. (2009). The patrimonial state and inter-ethnic conflicts in Nigeria. Ethnic and Racial Studies, 32(4), 679-697.

Joint Declaration between the Islamic Republic of Afghanistan and the United States of America for Bringing Peace to Afghanistan. (2020). [Joint Declaration]. https://www. state.gov/wp-content/uploads/2020/02/02 29.20-US-Afghanistan-Joint-Declaration. pdf.

Jonkman, S.N. \& Kelman, I. (2005). An analysis of the causes and circumstances of flood disaster deaths. Disasters, 29(1), 75-97.

Keele, L., Stevenson, R.T. \& Elwert, F. (2020). The causal interpretation of estimated associations in regression models. Political Science Research and Methods, 8(1), 1-13.

Maizland, L. (2020, March 2). U.S.-Taliban Peace Deal: What to Know. Council on Foreign Relations. https://www.cfr.org/backgrounder/us-taliban-peace-deal-agreement-afghanistan-w Marshall, M.G., Jaggers, K. \& Gurr, T.R. (2002). 'Polity IV dataset.'

Marty, F. J. (2021, February 1). The US-Taliban Deal: A Year Later. The Diplomat. 
https://thediplomat. com/2021/01/the-us-taliban-deal-a-year-later/.

Raleigh, C., \& Kishi, R. (2020). Hired Guns: Using Pro-Government Militias for Political Competition. Terrorism and Political Violence, 32(3), 582-603.

Roggio, B., \& Gutowski, A. (2021). Mapping Taliban Control in Afghanistan [Map]. FDD's Long War Journal. https://www. longwarjournal.org/mapping-taliban-control-in-afghanistan.

Roodman, D. (2009). A note on the theme of too many instruments. Oxford Bulletin of Economics and statistics, 71(1), pp.135-158.

Sinno, A. (2015). Partisan Intervention and the Transformation of Afghanistan's Civil War. The American Historical Review, 120(5), 1811-1828.

Tollefsen, A.F., Strand, H. \& Buhaug, H. (2012). PRIO-GRID: A unified spatial data structure. Journal of Peace Research, 49(2), pp.363-374.

USSD. 2020. Agreement for Bringing Peace to Afghanistan between the Islamic Emirate of Afghanistan which is not recognized by the United States as a state and is known as the Taliban and the United States of America. [Peace Agreement]. https://www.state.gov/ wp-content/uploads/2020/02/Agreement-For-Bringing-Peace-to-Afghanistan-02.29 . 20.pdf. 